\title{
A review of hydrogen technologies and engineering solutions for railway vehicle design and operations
}

\author{
Yan Sun $^{1} \cdot$ M. Anwar ${ }^{1}$ N. M. S. Hassan ${ }^{1} \cdot$ Maksym Spiryagin $^{1} \cdot$ Colin $_{\text {Cole }}{ }^{1}$
}

Received: 13 May 2021/Revised: 8 August 2021 / Accepted: 18 August 2021/Published online: 1 October 2021

(C) The Author(s) 2021

\begin{abstract}
Interest in hydrogen-powered rail vehicles has gradually increased worldwide over recent decades due to the global pressure on reduction in greenhouse gas emissions, technology availability, and multiple options of power supply. In the past, research and development have been primarily focusing on light rail and regional trains, but the interest in hydrogen-powered freight and heavy haul trains is also growing. The review shows that some technical feasibility has been demonstrated from the research and experiments on proof-of-concept designs. Several rail vehicles powered by hydrogen either are currently operating or are the subject of experimental programmes. The paper identifies that fuel cell technology is well developed and has obvious application in providing electrical traction power, while hydrogen combustion in traditional IC engines and gas turbines is not yet well developed. The need for on-board energy storage is discussed along with the benefits of energy management and control systems.
\end{abstract}

Keywords Hydrogen - Fuel cells · Hybrid power - Rail vehicles $\cdot$ Greenhouse gas emissions

$\begin{array}{ll}\text { Abbreviations } \\ \text { ADVISOR } & \text { Advanced vehicle simulator } \\ \text { AFC } & \text { Alkaline fuel cell } \\ \mathrm{CFT} & \text { Conventionally fuelled train } \\ \mathrm{CFV} & \text { Private conventionally fuelled vehicle } \\ \mathrm{Cu}-\mathrm{Cl} & \text { Copper-chlorine }\end{array}$

Yan Sun

y.q.sun@cqu.edu.au

1 Centre for Railway Engineering, Central Queensland

University, Rockhampton, QLD, Australia
ECMS Equivalent consumption minimisation strategy

EMCS Energy management and control strategy

ESS Energy storage system

FA Firefly algorithm

FC Fuel cell

FL Fuzzy logic

FW Flywheel

GHG Greenhouse gas

GTW Grand Trunk Western

HES Hybrid energy system

ICE Internal combustion engine

IPF Improved pathfinder

LIB Lithium-ion battery

LPG Liquefied petroleum gas

MCFC Molten carbonate fuel cell

PAFC Phosphoric acid fuel cell

PEMFC Polymer electrolyte membrane fuel cell or proton-exchange membrane fuel cell

PMP Pontryagin's minimum principle

PSO Particle swarm optimisation

SC Supercapacitor

SMR Steam methane reforming

SOFC Solid oxide fuel cell

SOFC-GT SOFC-gas turbine

SVR Support vector regression

WTW Well to wheel 


\section{Introduction}

With the development of rail transportation, there are mainly two primary systems at present in terms of power supply: one is railway system electrification (i.e. via overhead catenary or third rail) and the other the on-board diesel engine generated electricity. Introduced in Germany by Siemens in 1879 [1], the railway electrification systems are mainly applied for urban railways, high-speed trains, and high-density operations. On the other hand, on-board diesel-electric systems were introduced in the USA in the 1920s [2]. Diesel-electric systems were initially popular in North America and nowadays are the most common freight locomotive around the world. The popularity of diesel engines in rail applications is due to the high compression ratio of diesel engines and the diesel ignition process which achieves up $45 \%$ thermal efficiency. The connected electric drive system, alternator, and traction motors deliver typically $88 \%$ of this energy to the wheels. However, the diesel fuel combustion with air causes harmful emissions that impact air quality and result in greenhouse gases (GHG). Currently, modern science and technology have provided options for on-board power supply which can be considered to reduce harmful emissions and allow rail transportation using clean power sources, avoiding primary fossil fuels. Of particular interest is the use of hydrogen fuel cells (FC) which is a clean (zero emission) on-board source of electrical power. Such alternative clean power systems can be hybridised with traditional diesel engine systems or hybridised with energy storage systems (ESS) consisting of batteries and/or supercapacitors and/or flywheels.

Conventional locomotives employing on-board diesel power systems contribute to environmental issues due to $\mathrm{CO}_{2}$ emissions and related pollutions [3]. The increasing concerns about global warming have contributed to the response of the need to minimise GHG. As the nations of the world are working together to combat global climate change, rail transportation is seen as an area that can be considered for zero emission or clean technologies. It is believed $[4,5]$ that the first hydrogen locomotive was developed, designed, and demonstrated in the USA in 2002. Initially, for the proof of concept, a mining locomotive was powered by the polymer electrolyte membrane FC (PEMFC) only, with metal hydride storage and batteries. Subsequently, five mining locomotives were introduced for commercial operation in South Africa in 2012 [5]. However, for a long time, much attention has been focused on the research and development of hydrogen FCpowered passenger vehicles. In Japan, JR East trialled a rail car during 2006 to 2007 , powered by a $130 \mathrm{~kW}$ FC system, a 350 bar $\mathrm{H}_{2}$ storage device and $19 \mathrm{kWh}$ batteries, with the maximum speed reaching $100 \mathrm{~km} / \mathrm{h}$ [5]. During 2007 to
2008, the Japanese Railway Technical Research Institute tested two rail cars powered by a $120 \mathrm{~kW} \mathrm{FC} \mathrm{system,} \mathrm{a}$ $350 \mathrm{bar}_{2}$ storage device, and $36 \mathrm{kWh}$ batteries [5]. In 2016, it was claimed that the train named "the Coradia iLint" manufactured by Alstom was the world's first passenger train powered by a hydrogen FC, covering up to $1,000 \mathrm{~km}$ and reaching a maximum speed of up to $140 \mathrm{~km} / \mathrm{h}$ [6]. This zeroemission train emits low noise and only steam and condensed water as exhaust. This is a significant train because it combines various innovative elements: clean energy conversion, flexible battery energy storage in batteries, and smart management of traction power. In June 2019, the first hydrogen FC train in the UK was running on the tracks, which marks a milestone for clean rail transportation in the world [7]. The train named "HydroFlex" is a hybrid model intended to draw a greater proportion of its power from overhead lines or third rails, while the hydrogen FC can be used where either supply is unavailable. The driving system was held in one car, including $20 \mathrm{~kg}$ of hydrogen which is stored in four highpressure tanks, a $100-\mathrm{kW}$ proton-exchange membrane fuel cell (PEMFC), and 200-kW of lithium-ion batteries (LIBs). The hydrogen is transmitted into the FC where it chemically reacts to yield heat, water, and electricity which in turn either feeds into the traction motors to drive the train or is stored in the batteries for usage in peak times.

Although it has been little noticed, some promising development has been taking place in the rail heavy haul industry. An example $[8,9]$ in the USA was to retrofit a 109-t diesel-electric shunting locomotive with a power supply of PEMFC to power a $1.2 \mathrm{MW}$ locomotive. This was a seven-year project beginning in 2003 and jointly commissioned by the governments of the USA and Japan. Its power supply system is composed of a 350 bar $\mathrm{H}_{2}$ storage with $\mathrm{H}_{2}$ weight of $68 \mathrm{~kg}, 250 \mathrm{~kW} \mathrm{FC}$ and $1250 \mathrm{~kW}$ lead-acid batteries. Recent developments indicate that hydrogen-powered rail vehicles can be independent from using fossil fuels like diesel at point of use, to cut back on GHG [10]. The overall energy supply chain, though, still might not be achieving net zero carbon as emissions induced during the generation of hydrogen are dependent on the production process. When hydrogen is produced from renewable energy sources or from solar powered electrolysis, the GHG generated can be near zero or zero.

Since 2002, the activities in the development of FC technology for the rail industry in both passenger and freight markets have been intensive. An analysis of FC rail technology, insights and feasibility tests, their key findings, and the ability of FC technology to provide the rail industry with lower running costs and increased performance was carried out, and their recent developments were identified [3]. The authors found that the literature had focused on four areas, namely (1) prototype design and analysis, (2) energy management, (3) feasibility and economic 
assessment, and (4) environmental performance. They emphasised that FC-based hybrid locomotives require the ability to substantially mitigate environmental pollution at comparable investment costs as diesel-based locomotives. Consequently, nearly 3,318 t/year of $\mathrm{CO}_{2}$ emissions are estimated to be reduced by replacing a conventional diesel locomotive with a $\mathrm{Cu}-\mathrm{Cl}$-based hydrogen PEMFC train $[3,11]$. Moreover, energy management systems utilising various control strategies have been verified to be efficient and beneficial for such locomotives, as these can effectively manage the power demands between FC and ESS. The present review covers the clean and sustainable rail transportation challenges and their solutions by the potential implementation of hydrogen FC technologies and ESS in rail transportation applications.

\subsection{Past and current development of rail transportation}

It is well known that the railways started in mines at the beginning of the nineteenth century. Their excellent performance has been demonstrated by transporting large freight volumes and large numbers of passengers. As the railways have developed into today, they still have advantages compared to other modes due to the steel wheel-rail contact, which results in lower rolling resistance. Capitalising on the lower rolling resistance and associated low power use, rail has provided high volume and high mass transportation services for almost two centuries in terms of energy and motive power in which the first century was dominated by steam [12-14]. Through the second half of the nineteenth century, the design of steam engines had not fundamentally changed, but more effective traction steam locomotives still dominated the world railways until the end of the first half of the twentieth century. They were challenged by the introduction of electrification and diesel tractions from the early 1920s aimed at reducing operating expenses.

An electric locomotive was originally demonstrated by Siemens in 1879 , where power was supplied through a third rail between the two running rails. At the beginning of the twentieth century, competitive diesel locomotives gradually came to the mainline railways with the lighter weight, high speeds, and streamlined appearance. Meanwhile, the development of steam locomotives had reached its practical limits with the lower energy conversion efficiency not able to compete with the fast-growing electric and diesel traction systems. It was evident also that there was not a clear winner between diesel-electric and fully electric locomotive options. Selections depended on applications and the available energy sources. The challenge to the operation of electric trains was, and still is, the very high infrastructure investment needed for railway system electrification (i.e. overhead catenary or third rail). Hence, for longer routes and lower traffic volume, the onboard diesel-electric traction took the advantage of electric traction with high traction effort and discarded the disadvantage of steam traction with low energy efficiency and the disadvantage of fully electric traction with high electrification infrastructure cost. Since the middle of the twentieth century, overhead catenary electrification and onboard diesel-electric tractions have been dominant in rail transportation.

Many factors including government policies, operational issues, and market-driven production requirements, etc., have, from time to time, made sections of the rail industry pursue different traction options. Possibilities have included alternatives such as biofuel, battery storage, natural gas, hydrogen [9]. For all of these choices, it is an objective that they will minimise pollution and reduce reliance on diesel and that they are cost-effective in rail operations. In addition, it has to be shown that the alternative is technically applicable for rail traction. Modern automobiles are advanced with technologies such as sensors, automatic gearing and driving, and with eco-friendly fuels [15]. Vehicles powered by petrol and diesel can be replaced with ones powered by gaseous fuels such as liquefied petroleum gas (LPG), natural gas, and hydrogen. Hydrogen has been deployed in some new automobile designs [15]. The advanced technologies in automobiles provide excellent examples for rail applications of hydrogen-powered vehicles. Hydrogen can be made from a flammable liquid hydrocarbon mixture called "naphtha" and utilised in compressed form. Hydrogen vehicles are usually designed to use fuel cells and an electric traction system. There has also been experimentation using hydrogen in internal combustion engines (ICE).

It has been proposed that, given these options, hydrogen is a possible energy carrier for on-board rail traction [9]. Firstly, hydrogen can be produced from multiple energy sources, and its powered systems can be made technically acceptable and implemented in rail traction systems. Secondly, the power components can be accommodated within the space available on a train and the permissible weight restrictions. Hydrogen-powered system's well-to-wheel (WTW) efficiency is similar to electric and diesel options, but the $\mathrm{CO}_{2}$ emissions are lower than diesel systems [9].

It was pointed out in [16] that using hybrid power systems combining FC and LIB is an effective approach to reduce the emissions of rail vehicles for non-electrified lines. Several challenges, including the implications of having hydrogen fuel cells on passenger services and options for the applications of ESS for hybrid systems, were addressed by the authors, and they expected that several technological breakthroughs would appear in the near future. Among them, the development of a rail vehicle 
FC hybrid system suitable for an efficient combination with current train control systems is a key issue to be solved, and the evaluation of safety with on-board hydrogen was another objective [16]. Safety evaluation standards and related regulations for high-pressure hydrogen containers and hydrogen manufacturing facilities must also be prepared for commercial services.

\subsection{Potential solutions}

As stated above, rail industry networks worldwide have been under pressure to confront global climate change. The currently available powertrain technologies potentially able to achieve the demands of reduced GHG and zero local emissions are electrification, battery, and various FCs. Historically, without pressure to reduce emissions, the high cost of overhead catenary electrification infrastructure has discouraged its adoption on heavy haul corridors and longhaul low traffic density freight corridors. Battery only locomotives are another path to electrification, but their recharge requirements could greatly restrict the uses of the system. These conditions mean that there are places where various battery and FC hybrids may find application. The recent breakthroughs of FC technologies in heavy-duty road vehicles suggest that practical technologies for rail can be developed.

Electricity can be produced in an FC by using clean hydrogen generated by renewable energy sources such as solar, wind, hydro or hydrogen-rich hydrocarbon fuels, and it is then fed directly into a rail vehicle propulsion system or stored in batteries [17]. An FC locomotive could be built with the same power capability as a diesel-electric one, but there are significant challenges with on-board fuel storage and/or the need for frequent refilling stations. The FC locomotive would, of course, be less noisy and have less vibration. If the storage/refilling problem could be solved, hydrogen FC technology could provide a long-term local zero emissions with fast refuelling techniques (like diesel), flexibility, self-electrification, integration with renewable energy sources, and a low-noise operation. It is pointed out in [17] that a PEMFC, which operates at moderate temperatures $\left(80^{\circ} \mathrm{C}\right)$ and is best fitted to non-permanent demand cycles, has been proposed for applications like light rail and trams, commuter and regional trains, shunt/ switch locomotives, and underground mine locomotives. A solid oxide fuel cell (SOFC), on the other hand, has higher efficiency than other types of FCs, but needs to work at a high operating temperature $\left(1,000{ }^{\circ} \mathrm{C}\right)$. Given the steady duty cycles of freight or heavy haul locomotives which meet the SOFC regime requirement, it has been seen as a promising technology for this type of rail transportation. The following tables list the data provided in some literature which would give the vision for the development of some hydrogen FC locomotives in the near future.

Table 1 shows some comparisons between two currently used diesel locomotives and their equivalent conceptual hydrogen $\left(\mathrm{H}_{2}\right)$ and $\mathrm{H}_{2}$ hybrid locomotives. From that table, the locomotive weight $(72-77 \mathrm{t})$ is much lighter than current freight and heavy haul locomotives (135-195 t), and the energy storage quantity is $1,500 \mathrm{~L}$ for the diesel locomotive which corresponds to comparable energy storage in the conceptual ones where the $\mathrm{H}_{2}$ mass is only required within the range of $186-294 \mathrm{~kg}$, noting that $\mathrm{H}_{2}$ has approximately three times the calorific value of diesel fuel per kg. For the $\mathrm{H}_{2}$ hybrid locomotive based on a class 150 diesel locomotive, the total volume of $\mathrm{FC}$, batteries and $\mathrm{H}_{2}$ tanks is about $48.6 \mathrm{~m}^{3}$, which can be met within the space of the current diesel locomotive if the apparatuses relating to diesel are removed [24]. The different energy storage quantities can satisfy the operations in the range of time required. Table 2 shows some comparisons between an electric train and its equivalent conceptual $\mathrm{H}_{2}$ and $\mathrm{H}_{2}$ hybrid trains. Due to the installation of $\mathrm{FC}$ and $\mathrm{H}_{2}$ tanks, etc., the extra $23.5 \mathrm{t}$ and $24.4 \mathrm{t}$ are added in the conceptual $\mathrm{H}_{2}$ and $\mathrm{H}_{2}$ hybrid trains, respectively. The $\mathrm{H}_{2}$ stored energy is enough for the daily usage and the installation of $\mathrm{FC}, \mathrm{H}_{2}$ tanks and batteries would not cause a space problem because their total volume is about $40 \mathrm{~m}^{3}$ [19]. If the energy demand is supplied by the feedstock of coal, the $\mathrm{H}_{2}$ hybrid train would save the most energy annually as the hydrogen is assumed to be produced by steam methane reforming (SMR).

Table 3 shows three types of PEMFC $\mathrm{H}_{2}$ hybrid locomotives, and among them, two are for shunting and one is for a tram. The first shunting locomotive in Table 3 is more powerful than the second one. There is no space problem for the installation of PEMFC, $\mathrm{H}_{2}$ tanks, and energy storage system (ESS) for these three locomotives. In addition, an extra $9 \mathrm{t}$ of ballast was required for the first shunting locomotive to satisfy the locomotive weight requirement. From these tables, for the light $\mathrm{H}_{2}$ and $\mathrm{H}_{2}$ hybrid locomotives for both freight and passenger trains, it is seen that on-board storage can be sufficient for daily usage if that usage is of limited trip duration. The problem of rapid refilling or exchanging $\mathrm{H}_{2}$ tanks will be one of the challenges in the future. Another challenge would be how a conceptual $\mathrm{H}_{2}$ hybrid locomotive for heavy haul transportation is designed. The existing heavy haul locomotive's diesel tank volume is about 10 times the size of the diesels presented in Table 1. The equivalent energy storage quantity would need extra wagons to carry the $\mathrm{H}_{2}$ tanks. Currently, the simulation and conceptual designs for a heavy haul $\mathrm{H}_{2}$ hybrid locomotive have not been found in the literature reviewed. 
Table 1 Locomotive comparisons

\begin{tabular}{|c|c|c|c|c|c|c|}
\hline \multirow{3}{*}{$\begin{array}{l}\text { Parameters } \\
\text { Mass (t) }\end{array}$} & \multirow{2}{*}{\multicolumn{3}{|c|}{$\frac{\text { Real and conceptual locomotives [20] }}{\text { Diesel GTWH } \text { GTW H}_{2} \text { hybrid GTW }}$}} & \multicolumn{3}{|c|}{ Real and conceptual locomotives [18] } \\
\hline & & & & \multicolumn{2}{|c|}{ Diesel class $150 \mathrm{H}_{2}$ class 150} & \multirow{2}{*}{$\frac{\mathrm{H}_{2} \text { hybrid class } 150}{76.15}$} \\
\hline & 72 & 77 & 72.7 & 76.15 & 77.3 & \\
\hline $\begin{array}{l}\text { Primary energy per } \\
\text { journey }(\mathrm{kWh})\end{array}$ & 1,548 & 1,017 & 690 & 1,228 & 692 & \\
\hline Energy from braking (kWh) & & & 138 & & & 120.45 \\
\hline Energy storage quantity (kWh) & 14,918 & 9,816 & 6624 & 14,918 & 8775 & 6194 \\
\hline Storage & $1,500 \mathrm{~L}$ & $\begin{array}{r}\mathrm{H}_{2} \text { mas } \\
2941\end{array}$ & $\begin{array}{l}\mathrm{H}_{2} \\
\mathrm{~g} \text { mass } 204 \mathrm{~kg}\end{array}$ & $1,500 \mathrm{~L}$ & $\mathrm{H}_{2}$ mass $263.5 \mathrm{~kg}$ & $\mathrm{H}_{2}$ mass $186 \mathrm{~kg}$ \\
\hline Max. power at wheels $(\mathrm{kW})$ & 470 & 504 & 470 & 349 & 422 & 349 \\
\hline Mover power $(\mathrm{kW})$ & 600 & 625 & 250 & 406 & 495 & 198 \\
\hline Power plant $(\mathrm{kW})$ & 572 & 609 & 207 & 425 & 482 & 158 \\
\hline ESS battery max. power $(\mathrm{kW})$ & & & 400 & & & 360 \\
\hline $\begin{array}{l}\text { Total mass of tank, FC, and } \\
\text { battery }(\mathrm{t})\end{array}$ & & & 7.447 & & & 3.406 \\
\hline Volume of FC and battery $\left(\mathrm{m}^{3}\right)$ & & & & & & $2.866 \mathrm{~m}^{3}$ \\
\hline Tank pressure & & & Power-module & & & 350 bar \\
\hline Tank total volume $\left(\mathrm{m}^{3}\right)$ & & & 29.36 & & & 48.6 \\
\hline Tank area & & & $(4.5 \mathrm{~m} \times 2.15 \mathrm{~m}$ & & & $23.18 \mathrm{~m}^{2}$ \\
\hline Journey time (min) & 94 & 94 & 94.5 & 103 & 100.1 & 102.9 \\
\hline Range time (h) & 16 & 16 & 16 & 20.85 & 21.17 & 19.89 \\
\hline
\end{tabular}

Table 2 Locomotive comparisons

\begin{tabular}{|c|c|c|c|}
\hline \multirow[t]{2}{*}{ Parameters } & \multicolumn{3}{|c|}{ Light rail train [19] } \\
\hline & Electric & $\mathrm{H}_{2}$ & $\begin{array}{l}\mathrm{H}_{2} \\
\text { hybrid }\end{array}$ \\
\hline Mass (t) & - & +23.5 & +24.4 \\
\hline Max. power output $(\mathrm{kW})$ & 2,280 & 2,700 & 2,700 \\
\hline Hydrogen stored energy (kWh) & & 23,165 & 23,181 \\
\hline Total tank mass $(\mathrm{t})$ & & 14 & 14 \\
\hline Tank volume $\left(\mathrm{m}^{3}\right)$ & & 27.5 & 27.5 \\
\hline FC mass $(t)$ & & 7.272 & 7.272 \\
\hline FC volume $\left(\mathrm{m}^{3}\right)$ & & 11.9 & 11.9 \\
\hline ESS capacitor mass $(\mathrm{kg})$ & & & 825 \\
\hline Mover power $(\mathrm{kW})$ & 600 & 625 & 250 \\
\hline Power plant $(\mathrm{kW})$ & 572 & 609 & 207 \\
\hline ESS battery max. power $(\mathrm{kW})$ & & & 400 \\
\hline Energy at wheel (daily) (kWh) & 10,238 & 11,331 & 11,382 \\
\hline $\begin{array}{l}\text { Energy demand (annually) } \\
\text { by feedstock } \\
\text { (coal) }(\mathrm{mWh})\end{array}$ & 18,626 & 4,088 & 2,885 \\
\hline Round trip time (min) & $44+\frac{26}{60}$ & $44+\frac{17}{60}$ & $44+\frac{18}{60}$ \\
\hline
\end{tabular}

\section{Review of fuel cells}

An FC is an electrochemical cell that is used to convert chemical energy, generated from the reaction of hydrogen and oxygen, into electrical energy [24]. Sir William Grove invented the first FC in 1838. However, nearly a century later, Francis Thomas Bacon invented the hydrogen-oxygen FC in 1932, which brought the first commercial use. The alkaline FC, also known as the Bacon FC after its inventor, has been used to provide power for satellites and space capsules in NASA since the mid-1960s. Since then, FCs have been applied for many other aspects, mainly for the backup power for commercial, industrial, and residential buildings, and in remote areas. The applications also include various FC vehicles, including automobiles, buses, boats, motorcycles, forklifts, and submarines, etc.

There are several types of FCs, and they all comprise an anode, a cathode, and an electrolyte as shown in Fig. 1. At the anode, fuel undergoes oxidation reactions with a catalyst, which generates protons (positively charged hydrogen ions) and electrons. The protons can move from anode to cathode through an electrolyte. At the same time, the electrons flow from anode to cathode through an external circuit, generating direct current (DC) electricity. At the cathode, protons, electrons, and oxygen react together with 
Table 3 Some hydrogen FC locomotives

\begin{tabular}{|c|c|c|c|}
\hline Parameters & Shunting locomotive [21] & Shunting locomotive [22] & Tram [23] \\
\hline Mass (t) & 127 & $\sim 45$ & $44.3-63.15$ \\
\hline Max. power output $(\mathrm{kW})$ & 2,280 & 2,700 & 2,700 \\
\hline FC type & PEMFC & PEMFC & PEMFC \\
\hline Max. power $(\mathrm{kW})$ & 300 & $120 \times 2$ & \\
\hline Continuous power $(\mathrm{kW})$ & 250 & & \\
\hline Rated power $(\mathrm{kW})$ & & & 150 \\
\hline Hydrogen mass $(\mathrm{kg})$ & 70 & 23 & 11.2 \\
\hline Tank mass $(\mathrm{t})$ & 1.4 & & \\
\hline Tank volume (L) & $2,870[10]$ & & 560 \\
\hline Tank pressure (MPa) & 35 & 35 & 35 \\
\hline Tank number & 14 [10] & 9 & \\
\hline ESS battery & Lead-acid $1.5 \mathrm{MW}$ for $5 \mathrm{~min}$ & Li-ion $600 \mathrm{~V}$ & Li-ion $150 \mathrm{~kW}, \mathrm{UC}(\mathrm{SC}) 130 \mathrm{~kW}$ \\
\hline Traction motor & $600 \mathrm{VDC}$ & PMSMS & $46.6 \mathrm{~kW}$ \\
\hline Traction force & $356 \mathrm{kN}$ (speed to $9.6 \mathrm{mph}$ ) & $36.5 \mathrm{kN}$ (cont.), $50 \mathrm{kN}$ (start) & $3 p, 392 \mathrm{~V}$ \\
\hline Adding mass $(\mathrm{t})$ & 9 & & \\
\hline Duty time (h) & $8-10$ & & 7.1 \\
\hline Distance $(\mathrm{km})$ & & & $\sim 71$ \\
\hline Speed $(\mathrm{km} / \mathrm{h})$ & 64 & Max. 65 & 36 \\
\hline
\end{tabular}

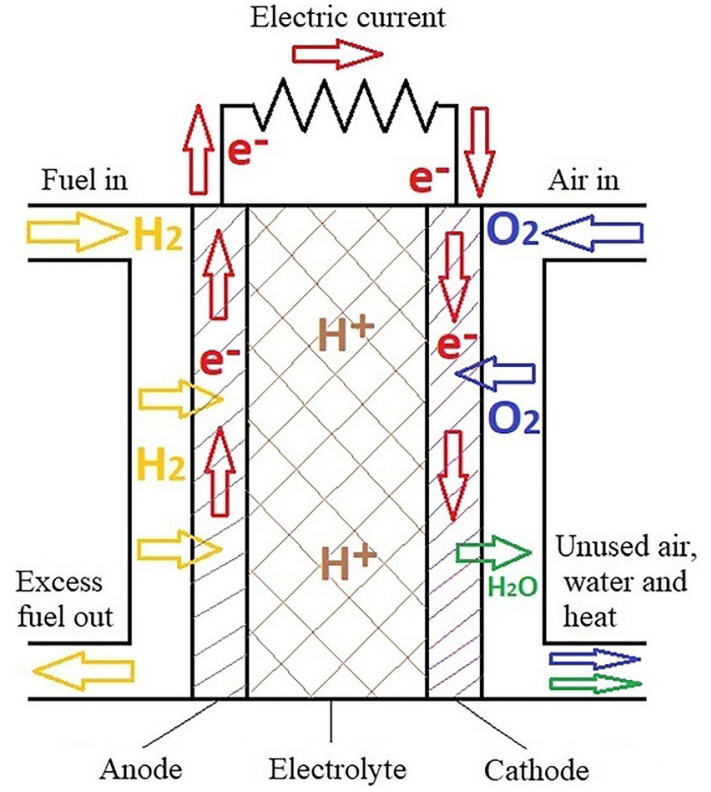

Fig. 1 An FC generalised design scheme

another catalyst, forming water, heat, and possibly other products depending on the fuel source. FCs can be classified by the start-up time, differing from $1 \mathrm{~s}$ for PEMFC to 10 min for SOFC. The energy efficiency of an FC is generally between $40 \%$ and $60 \%$.

Various types of FCs can be considered as rail vehicle power supplies with regard to performance, cost, reliability, and durability [25]. Higher temperature fuel cells are drawing more attention due to no use of expensive metal catalyst and because exhaust thermal energy can be managed efficiently with other thermal systems for cogeneration. Higher temperature fuel cells are SOFCs, and molten carbonate fuel cells (MCFCs), and lower temperature cells are PEMFCs, phosphoric acid fuel cells (PAFCs), and alkaline fuel cells (AFCs). Figure 2 shows some popular fuels cell technologies.

\subsection{Polymer electrolyte membrane fuel cells (PEMFCs)}

PEMFC contains a polymer electrolyte membrane (or proton-exchange membrane) (PEM), which can conduct $\mathrm{H}^{+}$ions, known as protons. One of the most common PEM materials is called Nafion because of its excellent thermal and mechanical stability. An electro-catalyst is also required for the electrochemical reaction which occurs in PEMFC. For this reason, platinum black is commonly used as a catalyst. The catalyst is attached to the carbon paper or fabric and placed on the sides of the cell. The poisoning effect of carbon monoxide on its catalytic properties is a significant drawback of the platinum anode. Hydrogen is fed onto the anode, while humidified air is provided on the cathode. The electrochemical reaction is exothermic and that raises the FC temperature. So, the cooling system is implemented within the cell to ensure the Nafion membrane that works efficiently at lower than $100{ }^{\circ} \mathrm{C}$. Another difficulty of using this FC is the high cost of the metal 


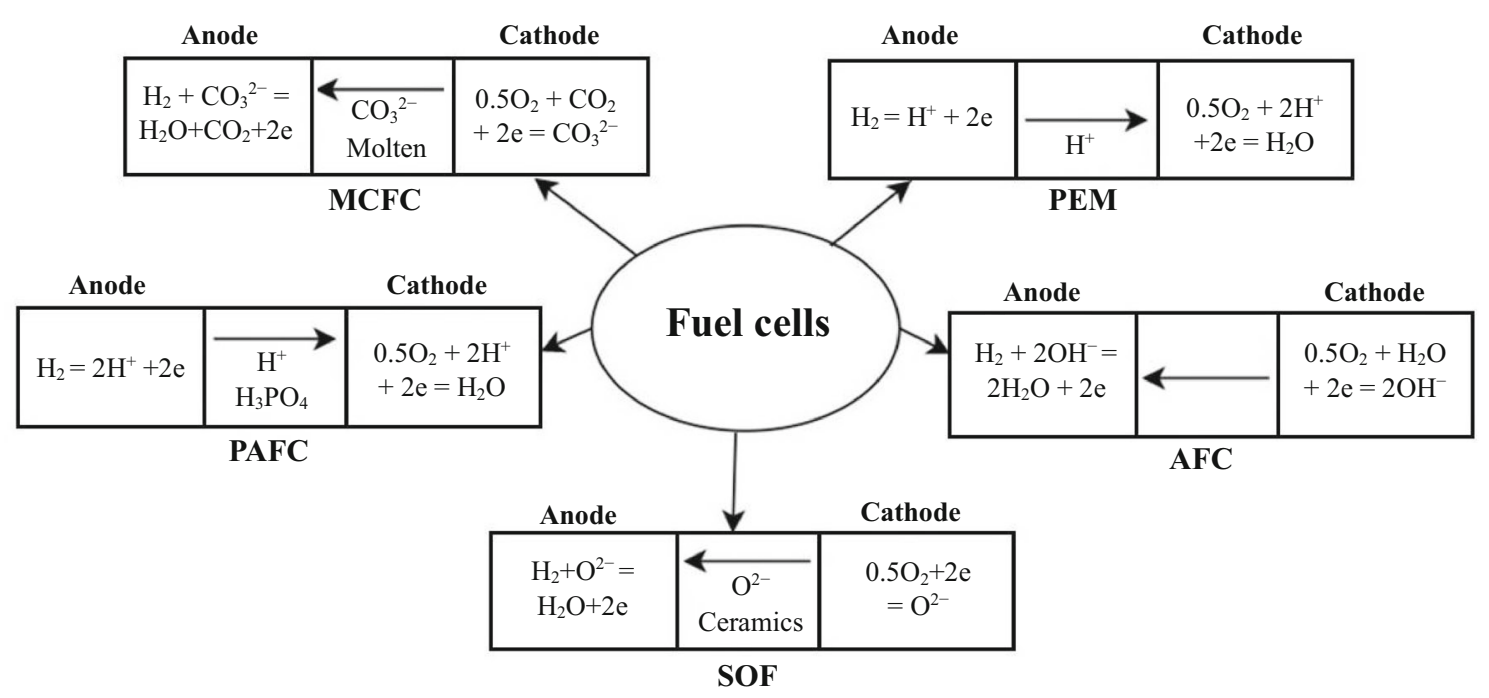

Fig. 2 Various fuel cell technologies

catalyst. However, the PEMFC has a rapid start-up and rapid shutdown functionality which makes it an excellent choice for multiple applications especially in the automobile and power-producing industries [26-28].

\subsection{Alkaline fuel cells (AFCs)}

AFC adopts an electrolyte alkaline in nature, which is usually potassium hydroxide of $35 \%-85 \%$ concentration. The $\mathrm{OH}^{-}$anions are produced by the cathodic reaction of oxygen with water molecules and then transmitted to the anode side by way of the conductive alkaline electrolyte. Hydrogen interacts with $\mathrm{OH}^{-}$anions to produce the electrical flows. AFC was the first type of FC that the USA invented and used in their spaceships. The temperature of the fuel cell remains lower than $100{ }^{\circ} \mathrm{C}$, and the by-product of the electrochemical reaction remains in the water form. $\mathrm{AFC}$ can be used to produce power from 1 to $100 \mathrm{~kW}$ with nearly $60 \%$ energy efficiency. The benefit of AFC over PEM is that there is no use of an expensive metal catalyst. Nickel metal-based electrodes are generally used. The major drawback of AFC is that it deteriorates significantly with the presence of $\mathrm{CO}_{2}$ molecules in the $\mathrm{FC}$ as they react with the electrolyte molecules and form non-desired compounds [29]. However, with the use of pure oxygen and hydrogen, the service lifetime of AFC can be achieved up to 15,000 or $20,000 \mathrm{~h} \mathrm{[30] \text {. }}$

\subsection{Solid oxide fuel cells (SOFCs)}

An SOFC is constructed from solid oxide electrolytes with a very low thickness. The thickness of the electrolyte is normally a few microns. The electrolyte feature consists of the transmission of oxygen anions or protons from hydrogen. SOFCs are categorised according to the electrolyte capability of transmitting negatively charged anions or positively charged cations into either oxygen anion conducting electrolyte-based SOFCs or proton-conducting electrolyte-based SOFCs. The operating temperature of SOFC is quite high $\left(800-1,000{ }^{\circ} \mathrm{C}\right)$, and it does not perform well at a low temperature due to the considerable reduction in ionic conductivity of the electrolyte. It is used for producing higher power outputs (up to $2 \mathrm{MW}$ ) with an energy efficiency of $60 \%$ [31]. Both tubular and planar configurations are used for configuring SOFC and hightemperature-resistant materials such as ceramics, metals, composites, and alloys are used as components. That involves higher costs of materials and sophisticated designs for producing the thin electrolyte and the assembly. Other types of fuels such as methane, methanol, ethanol, and ammonia have been under investigation with SOFC for optimising performance using minimum resources.

\subsection{Phosphoric acid fuel cells (PAFCs)}

The working principle of PAFC and PEMFC is similar to an electrolyte conducts $\mathrm{H}^{+}$protons from the anode to the cathode of the FC. The basic difference in the PAFC is that phosphoric acid embedded with bonded Teflon in a permeable silicon carbide structure. The output of the PAFC can range from 5 to $400 \mathrm{~kW}$, and the energy efficiency is a bit lower $(40 \%)$ than other FC types. Bipolar plates from different materials and designs are investigated for connecting separate cells $[8,9,32]$. It generally operates effectively at more than $200{ }^{\circ} \mathrm{C}$, and this higher temperature reduces the platinum catalyst poisoning effect which 
leads to a longer lifetime of the FC. The maximum lifetime of this PAFC system that can be achieved is about 40,000 h. Japanese companies like Mitsubishi, Fuji Electric, Sanyo, and Toshiba have been involved in researching and developing PAFC systems. It is mainly used in stationary power generation systems $[33,34]$.

\subsection{Molten carbonate fuel cells (MCFCs)}

The MCFCs enable the electrolyte to be put into a permeable matrix made of ceramic material being a molten mixture of alkaline and alkaline earth metal carbonates. Lithium aluminate is commonly used as the ceramic permeable matrix material. In the matrix, the thickness and the electrolyte are in the micrometre range. The operating temperature of the $\mathrm{FC}$ is about 600 to $650{ }^{\circ} \mathrm{C}$, and the power output of $300 \mathrm{~kW}$ to $3 \mathrm{MW}$ can be achieved with an efficiency of $50 \%$. Nickel chromium alloy is used as the anode, and permeable nickel oxide doped in lithium is utilised as the cathode. Different designs and materials are used for bipolar plates to connect separate cells. The electrochemical reaction between the carbon dioxide and oxygen molecules at the cathode forms the carbonated ions. At the anode, carbon dioxide is also formed by the electrochemical reaction. Thus, carbon dioxide can be fed to the cathode for the half-cell cathodic reaction [3]. The MCFC system is used in power generation industries and is getting popular due to less maintenance, low cost, and higher power output. However, an MCFC has lower power density $\left(120-160 \mathrm{~mW} / \mathrm{cm}^{2}\right)$ compared to an SOFC $\left(400-500 \mathrm{~mW} / \mathrm{cm}^{2}\right)$. Researchers around the world and major organisations like GenCell, Ansaldo, CFC Solutions, and Doosan are investigating the potential use of MCFCs by focusing on new catalysts, electrode materials, and their effectiveness at higher temperatures $[35,36]$.

\section{Review of hydrogen-powered vehicles}

\subsection{Fuel cell systems}

Based on the temperature of operation, there are two types of FCs, including the low-temperature FCs such as AFC and PEMFC and the high-temperature FCs such as SOFC and MCFC. Due to the low temperature and short start-up time, PEMFC has been used in urban light rail transportation. It is pointed out by [37] that, in most automotive applications, the PEMFC is preferred due to the lower temperature of operation. High-temperature FCs are attractive because they do not require the costly metal catalysts that PEMFC need. Because freight and heavy haul locomotives are usually used for long periods, a little longer start-up time for the FC is not a serious concern.
Therefore, the high-temperature SOFC could be suitable for this application. Some advantages of SOFC over PEMFC are as follows [32]: (1) fuel types are more flexible, including hydrogen and hydrocarbons, e.g. diesel, biodiesel, and clean coal gas; (2) more tolerance to the existence of impurities in reactant gases; (3) less costly metal catalyst can be used; (4) higher quality thermal product $\left(600-1,000{ }^{\circ} \mathrm{C}\right)$ can serve other components and systems or for cogeneration; (5) lower activation losses and higher overall conversion efficiencies; (6) simpler fuel processing process. However, the design needs to consider heat protection as a safety procedure for the high temperature of operation associated with SOFC.

It is known that a practical FC-powered rail vehicle should be hybridised. An on-board hybrid-powered rail vehicle would be expected to have a primary power plant (FC), an energy storage system (ESS), and an energy control and management system [37]. The ESS comprises a bank of batteries and/or a set of supercapacitors (SCs) and/ or a group of flywheels (FW). These kinds of hybrid rail vehicles can be used in several applications, including freight and heavy haul transportation, yard shunting, regional and intercity trains and light rail systems. Depending on duty cycles and regenerative braking, some of these applications can save the costs in energy consumption and overhead catenary infrastructure and so reduce fuel consumption, emissions, and GHG.

The potential of hydrogen FC-powered rail vehicles has drawn a lot of interest, and countries including China, India, Germany, UK, etc., are developing hydrogen FCpowered rail vehicles. China's first hydrogen FC train was developed in 2010 [38]. A tram powered with a $200 \mathrm{~kW}$ PEMFC was developed in China in 2015 [17] and has been in commercial service since 2019, with the maximum speed of $70 \mathrm{~km} / \mathrm{h}$. Germany's first hydrogen FC-powered commuter train (Coradia iLint) was successfully operational in 2017 [39]. The UK's first hydrogen-powered train "HydroFlex" was in service in 2019.

Hydrogen FC has been considered as the primary power sources for on-board rail vehicles to minimise the demand for fossil fuels and GHG emissions [37]. To use hydrogen FC for a rail vehicle, a hybrid system is usually designed which consists of an FC and an ESS. Therefore, a control algorithm is also required to manage the demanded power output from energy sources and to maintain suitable charging for the ESS. In an ESS design, the most important component to select is the storage, usually batteries. The selection of economic, compact, and reliable batteries is essential. Currently, lead-acid, lithium-ion (LI), nickel-cadmium (NiCad), and nickel-metal hydride (NiMH) are most widely used [37]. Among them, LI batteries are more expensive and used where high energy densities and low weight are crucially important. NiCad 
batteries are toxic, not environmentally friendly, need regular maintenance, and are used where long lifetime, high discharge rate, and reasonable price are required. $\mathrm{NiMH}$ batteries are more energy dense, but more expensive and not as reliable as lead-acid batteries. In rail applications, weight and volume might not always be a design constraint, depending on the trip duration and installed power requirements and as for steam locomotives, fuels can be stored in additional wagons (tenders). The two important factors of cost and reliability are considered. In [37], it was thought that lead-acid batteries with their excellent reliability performance are the most economical. More important is that a wide variety of commercial models are available which can satisfy the high power and energy demands for the applications. Along with batteries, supercapacitors (SC) and/or flywheels (FW) are possible energy storage devices but are seldom seen in rail vehicle applications. Supercapacitors can respond faster than batteries to supply and storage power demands.

The design of a hydrogen FC-powered hybrid rail vehicle can be performed with mathematical modelling and theoretical calculations or simulations. The tractive effort offered by a diesel locomotive on a user-defined drive cycle was used to design a hydrogen FC-powered hybrid energy system for use in India [40, 41]. A simulation package called advanced vehicle simulator (ADVISOR) was applied to undertake modelling and to conduct performance analysis. Because of the PEMFC's slow response towards sudden loading fluctuations, it must be hybridised with an ESS (usually a battery). Hence, in the energy system, the PEMFC provides the steady electrical supply, while the batteries support the faster moving dynamics of the locomotive system for both traction and dynamic braking. The rating requirements for the components in the hybrid energy system are then determined. The design achieved simulations such that the hybrid energy system satisfied the power demand of the diesel locomotive, and the state of charge $\left(S_{\mathrm{c}}\right)$ of batteries was maintained within the limits.

It is pointed out in [42] that one of the key challenges towards the large-scale rail vehicle applications is the slow response of the PEMFC to dynamic loadings because the loading demand fluctuations may result in the PEMFC experiencing fuel starvation, bleeding, and membrane drying problems which will deteriorate the PEMFC service life. Therefore, a hybrid energy system is essential to a rail vehicle power system integrating a hydrogen FC as the main power supply and batteries and/or SC and/or FW as an ESS. A lot of research work has been done for hydrogen FC-powered hybrid rail vehicle systems, especially on the energy management and control strategy (EMCS) which is responsible for energy allocation between the FC and ESS to maximise the performance [23, 43-67].

\subsection{Combustion systems}

Usage of hydrogen as a direct fuel is extremely challenging due to its high flammability, as well as being difficult to store, transport, and handle [68, 69]. However, hydrogen in its lean mixture (low air-fuel ratio) can be used economically in the direct combustion engine to improve exhaust emissions but can produce higher NOx due to less air-fuel mixing time. To minimise those problems, a completely new engine system needs to be designed, which often cannot be obtained by retrofitting an old existing engine.

A dynamic SOFC-gas turbine (SOFC-GT) hybrid energy system model was proposed in [70] for a long-haul freight locomotive. The proposed system's operational capabilities on three fuels, namely diesel fuel, natural gas, and hydrogen, were investigated. The results show that it is feasible for the system to operate on these three fuels, with favourable efficiencies and acceptable dynamic responses. It is demonstrated that the SOFC can be hybridised with a gas turbine, allowing for many synergistic benefits. Such a system can potentially achieve efficiencies above $60 \%$, actually producing zero emissions and low noise. The feasibility of the SOFC-GT hybrid energy system in a freight locomotive was assessed in [71]. The SOFC-GT space requirement is similar to current diesel engines, and a mathematical model for an SOFC-GT system was used for the simulation of kinematics and power notching along a representative route. Similarly, the simulations of an SOFC-GT hybrid system in a locomotive were reported some 7 years later in [72]. The system comprising a 2.8 MW SOFC, and a 500-kW GT was simulated to haul 480-t freight per 120-t locomotive on a specific route at an average speed of $45 \mathrm{mph}(72 \mathrm{~km} / \mathrm{h})$. The track grades were used to study the power demand fluctuations, and the net system efficiency and the smooth operation in the highly dynamic route were improved by adding lithium-ion battery (LIB) storage in the model. The power demand was met without an obvious disruption to the locomotive speed. The results indicate that a prototype of the proposed system could be developed, which is promising for the future rail freight transportation. From a technical viewpoint and the analysis, it was concluded that SOFC-based hybrid locomotives could be developed to replace conventional diesel locomotives [25].

\section{Modelling and design of hydrogen rail vehicles}

\subsection{Hydrogen rail vehicle energy modelling}

It is believed that comprehensive mathematical modelling and advanced simulation methods can provide precise insight into the issues arising in the designs and 
optimisations of hydrogen fuel cell (FC)-powered hybrid rail vehicles $[73,74]$. The main objective is to use a reputable train model and suitable simulation techniques to study the performance of a hydrogen FC-powered hybrid train system consisting of traction motors, hydrogen FC and ESS, etc. To numerically examine such a rail vehicle system, electrochemical, logical, and physical equations are adopted to build numerical models. Five subsystems can be defined according to their roles within such a system [75-77]:

(1) Power demand modelling-to decide the power demand of a rail vehicle regarding traction force and vehicle speed, having the track topography and speed limits as input.

(2) Energy source modelling - to determine hydrogen FC and ESS (battery, SC, and FW), which are essential components for supplying the power and energy required by the vehicle.

(3) Power electronic device modelling-DC/DC converters to link energy sources to DC bus and DC/AC inverters to convert $\mathrm{DC}$ power from the energy sources to AC power.

(4) Driving elements - to consider the electric motor and gearbox, and to transmit and convert mechanical power between motor and wheelset.

(5) Energy management and control system (EMCS) - to optimally control all the components, to make each subsystem collaborate perfectly, and to accurately set the power for the energy sources.

The topology of a hydrogen FC-powered hybrid system is shown in Fig. 3 [78, 79]. In a powertrain's traction process, FC and ESS work together to supply energy for the powertrain, and an EMCS is used to regulate the power distribution of FC and ESS. During braking, motors generate braking power, and it flows into a bidirectional $\mathrm{DC} /$ $\mathrm{AC}$ inverter and then a bidirectional DC/DC converter, and finally, the ESS stores the regenerative braking energy and releases it when needed, improving overall system efficiency. Hydrogen FC-powered hybrid rail vehicles comprising multiple energy sources have many benefits. The FC can work as a prime mover and supply the total energy demand. Thus, it does not need to fulfil the power variations and works in quasi-steady-state conditions, reaching high performance and an expected long lifetime. Conversely, the ESS is suited to supply the power and energy variations. Thus, the system can supply both needs. The ESS can be composed of one or more components based on the drive cycle parameters $[20,80]$. The drive cycle can be any railway line and can present different power and energy variations (such as acceleration, deceleration, idle, and start-stop operations). An EMCS is responsible for supplying the power needed by optimising the power from

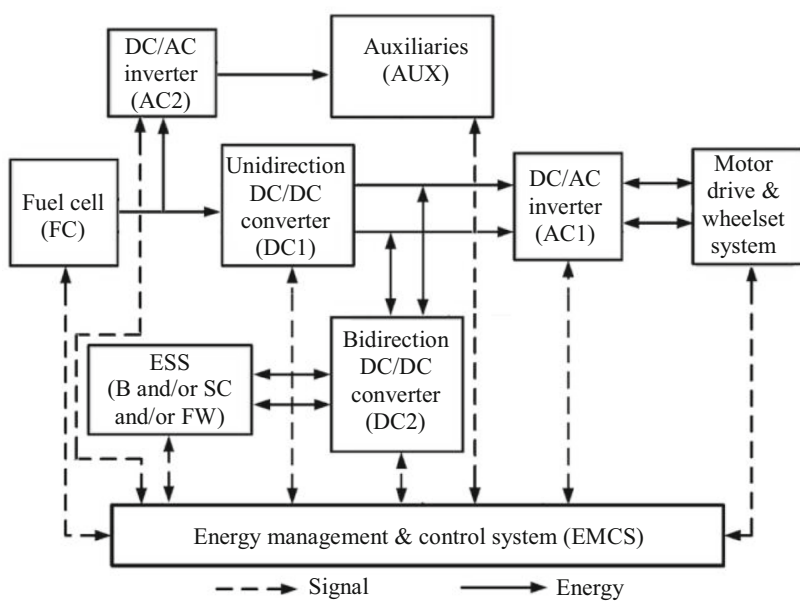

Fig. 3 Hydrogen hybrid system [78, 79]. The B, SC and FW stand for battery, supercapacitor and flywheel, respectively

two or three energy sources (depending on whether supercapacitors are also used). For example, an FC-B-SC powertrain can be the best selection for a drive cycle where the battery provides the large energy variations, and the supercapacitor covers the very short-term power peaks [81]. The more components used, the more complex are the powertrains and control systems. A simple description of hydrogen FC energy source modelling is given as follows.

\subsubsection{Hydrogen FC modelling}

Based on an electrochemical model, the FC model can be described, and its output variables are voltage, current, and hydrogen consumption. The model is usually built with the following simplifications; namely, gases are considered ideal, FC is fed with hydrogen and air, and humidifier and air cooler are considered ideal. The hydrogen FC output voltage $[32,75,82]$ can be expressed by Eq. (1).

$V_{\text {stack }}=N_{\mathrm{c}} V_{\text {cell }}=N_{\mathrm{c}}\left(E_{\mathrm{N}}-V_{\text {act }}-V_{\text {ohm }}-V_{\text {conc }}\right)$,

where $V_{\text {stack }}$ is the stack voltage $(\mathrm{V}) ; N_{\mathrm{c}}$ is the number of FCs; $V_{\text {cell }}$ is the cell voltage $(\mathrm{V}) ; E_{\mathrm{N}}$ is the Nernst voltage $(\mathrm{V}) ; V_{\text {act }}$ is the activation overvoltage $(\mathrm{V}) ; V_{\mathrm{ohm}}$ is the Ohmic overvoltage (V); and $V_{\text {conc }}$ is the concentration over voltage $(\mathrm{V})$. Their relationship can be seen in [83].

When the output power of FC is $P_{\mathrm{FC}}(\mathrm{MJ})$, the efficiency and hydrogen consumption can be expressed as

$E_{\mathrm{FC}}=\frac{P_{\mathrm{FC}}}{m_{\mathrm{H} 2} H_{\mathrm{LH} 2}}$,

where $E_{\mathrm{FC}}$ and $m_{\mathrm{H} 2}$ are the efficiency and hydrogen consumption $(\mathrm{kg})$, respectively; $H_{\mathrm{LH} 2}$ is the low calorific heat value of hydrogen $(\mathrm{MJ} / \mathrm{kg})$. The efficiency of $\mathrm{FC}$ is related to its part load ratio (PLR), which is related to the ratio of 
the electrical output to the maximum power rating of $\mathrm{FC}$ [83].

\subsubsection{ESS modelling}

It is known that the primary component in an ESS is the battery which assists the hydrogen FC to supply sufficient power to the variable load $[32,75,82,84,85]$. The value of battery state of charge $\left(S_{\mathrm{c}}\right)$ is an important parameter that provides a crucial signal for EMCS. Precise determination of $S_{\mathrm{c}}$ is also vital for developing a suitable EMCS and improving the efficiency of the whole system. Battery modelling can be described as

$$
\left\{\begin{array}{l}
V=V_{\mathrm{oc}}\left(S_{\mathrm{c}}\right)-R\left(S_{\mathrm{c}}\right) \times I \\
S_{\mathrm{c}}(t+1)=S_{\mathrm{c}}(t)-\left(\int_{t}^{t+1} i \mathrm{~d} t\right) / Q
\end{array}\right.
$$

where $V$ and $I$ are the terminal voltage (V) and current (A), respectively; $S_{\mathrm{c}}$ is the state of charge; $V_{\mathrm{oc}}$ is the equivalent open-circuit voltage $(\mathrm{V}) ; R$ is internal resistance $(\Omega) ; i$ is the current (A); $t$ is the current instant (s); and $Q$ is the maximum capacity (As). These variables can be determined based on $S_{\mathrm{c}}$.

The supercapacitor or flywheel is a secondary component, which can be used to supply and store the power at a higher frequency than the battery. Its use is highly dependent upon the power demand features, i.e. peak energy, maximum power, and power frequency.

\subsubsection{Power demand modelling}

The descriptions of power demand modelling [73, 74] are given as follows. Based on the FC model, the power $\left(P_{\mathrm{FR}}\right)$ at the rail from the $\mathrm{FC}$ is thus given by

$P_{\mathrm{FR}}=\left(P_{\mathrm{FC}}-\frac{P_{\mathrm{AUX}}}{\eta_{\mathrm{AC} 2}}\right) \eta_{\mathrm{DC} 1} \eta_{\mathrm{AC} 1} \eta_{\mathrm{M}}$

where $P_{\mathrm{FC}}$ is the power output of FC $(\mathrm{kW}) ; P_{\mathrm{AUX}}$ is the constant power $(\mathrm{kW})$ required for auxiliaries supplied through the inverter with an efficiency $\eta_{\mathrm{AC} 2} ; \eta_{\mathrm{DC} 1}$ is the efficiency of the unidirectional DC/DC converter for FC; $\eta_{\mathrm{AC} 1}$ and $\eta_{\mathrm{M}}$ are the efficiencies of the DC/AC inverter and traction motor, respectively.

If the traction force $F_{\mathrm{t}}(\mathrm{kN})$ applied on the driving wheelset is positive, the power at the rail $P_{\mathrm{FR}}$ from the FC is given by Eq. (4). If the traction power needed $\left(P_{\mathrm{T}}\right)(\mathrm{kW})$ exceeds the power $\left(P_{\mathrm{FR}}\right)$ available from the $\mathrm{FC}$, additional power at the rail $P_{\mathrm{ESSR}}$ must be supplied by the ESS as follows:

$$
\begin{aligned}
P_{\mathrm{ESSR}} & =P_{\mathrm{T}}-P_{\mathrm{FR}} \\
& =F_{\mathrm{t}} \times v-\left(P_{\mathrm{FC}}-\frac{P_{\mathrm{AUX}}}{\eta_{\mathrm{AC} 2}}\right) \eta_{\mathrm{DC} 1} \eta_{\mathrm{AC} 1} \eta_{\mathrm{M}},
\end{aligned}
$$

where $v$ is the running speed $(\mathrm{m} / \mathrm{s})$. This additional power at the rail is related to the ESS power $P_{\mathrm{ESS}}(\mathrm{kW})$ through the equation:

$P_{\mathrm{ESSR}}=\eta_{\mathrm{DC} 2} \eta_{\mathrm{AC} 1} \eta_{\mathrm{M}} P_{\mathrm{ESS}}$,

where $\eta_{\mathrm{DC} 2}$ is the efficiency of the bidirectional DC/DC converter. Hence, from Eqs. (5) and (6), the power drawn from the ESS is given by

$P_{\mathrm{ESS}}=\frac{F_{\mathrm{t}} \times v}{\eta_{\mathrm{DC} 2} \eta_{\mathrm{AC} 1} \eta_{\mathrm{M}}}-\left(P_{\mathrm{FC}}-\frac{P_{\mathrm{AUX}}}{\eta_{\mathrm{AC} 2}}\right) \frac{\eta_{\mathrm{DC} 1}}{\eta_{\mathrm{DC} 2}}$.

If $F_{\mathrm{t}}$ is positive and the traction power at the rail $P_{\mathrm{T}}$ $(\mathrm{kW})$ is less than the power $\left(P_{\mathrm{FR}}\right)(\mathrm{kW})$ available from the FC, part of the FC output may be used for traction and part for recharging the ESS. Losses that arise in the ESS are accounted for through the factor $\eta_{\text {ESS }}$ which is the efficiency representing the percentage of charging power converted into usable stored energy. The useful power for ESS charging (provided it is less than the specified maximum $\left.P_{\text {ESSMax }}(\mathrm{kW})\right)$ is then given by

$P_{\mathrm{ESS}}=\left[\left(P_{\mathrm{FC}}-\frac{P_{\mathrm{AUX}}}{\eta_{\mathrm{AC} 2}}\right) \eta_{\mathrm{DC} 1} \eta_{\mathrm{AC} 1} \eta_{\mathrm{M}}-F_{\mathrm{t}} \times v\right] \eta_{\mathrm{DC} 2} \eta_{\mathrm{AC} 1} \eta_{\mathrm{M}} \eta_{\mathrm{ESS}}$

During coasting, no power is drawn by the traction motors, and the power from the FC is used for ESS charging, giving

$P_{\mathrm{ESS}}=\left(P_{\mathrm{FC}}-\frac{P_{\mathrm{AUX}}}{\eta_{\mathrm{AC} 2}}\right) \eta_{\mathrm{DC} 1} \eta_{\mathrm{DC} 2} \eta_{\mathrm{ESS}}$.

During regenerative braking, the power for ESS charging is limited to the maximum that the traction motor can provide in generator mode, and the power for the ESS is also limited by the maximum power $\left(P_{\text {ESSMax }}\right)$ that can be handled by the ESS itself. Subject to those limits, the effective power at the ESS input, $P_{\text {ESS }}(\mathrm{kW})$, during regenerative braking is given by

$P_{\mathrm{ESS}}=\left(F_{\mathrm{t}} \times v\right) \eta_{\mathrm{DC} 2} \eta_{\mathrm{AC} 1} \eta_{\mathrm{M}} \eta_{\mathrm{ESS}} \leq P_{\mathrm{ESSMax}} \cdot$

Regenerative braking is used in the simulation model until the train speed drops to the threshold value $v_{\text {th }}(\mathrm{m} / \mathrm{s})$ at which braking effort limiting occurs.

\subsection{Prototype design and analyses}

Several researchers [86, 87]completed an energy system analysis of an on-board hydrogen FC-powered hybrid rail vehicle in a real drive cycle with system sizing made to accomplish the performance expected with the most 
suitable power levels and using components available on the market. The authors showed that hydrogen could be used as an energy carrier. Globally, there are several prototypes designed and tested for their initial development. In 2012, a team of the University of Birmingham designed a prototype locomotive with a 1:5 scale of a real one, powered by a $1.1 \mathrm{~kW}$ hydrogen PEMFC, which provides electricity to the traction motors or charges the on-board lead-acid batteries [88], whose configuration is shown in Fig. 4 [80]. The prototyped locomotive runs on a 10.25inch $(260.35 \mathrm{~mm})$ gauge track, and the tests were conducted for the speeds of $2,6,7$, and $10 \mathrm{~km} / \mathrm{h}$. The vehicle was the UK's first hydrogen FC-powered locomotive and was called Hydrogen Pioneer [88]. Testing established a proof of the concept of a hydrogen FC-powered hybrid locomotive. The power plant, vehicle efficiency, and performance of the hybrid system were recorded [88]. The overall duty cycle efficiency of the power plant was observed to vary from $28 \%$ to $40 \%$, and the peak power demanded by acceleration was supplied by the batterypack, while average power during the duty cycle was provided by the FC stack. The results indicated that the traction system could be applied to full-scale locomotives.

The first locomotive to utilise a PEMFC power plant in China started development in 2012 [22, 89, 90]. The testing results were intended to supply fundamental data for further improvements of the PEMFC-powered locomotive or hybrid ones. Locomotives with a PEMFC as the main power source and a high-voltage LIB pack to supply startup power could be zero emission.

A hydrogen rail powertrain was conceptualised and consisted of three different subsystems of the FC, battery, and hydrogen storage systems [91]. A backward design approach is presented to evaluate the power demand according to a "route simulation data" method. The powertrain components are then conceptually sized based on the determined duty cycle. A prototype hydrogen FCpowered hybrid shunting locomotive for rail applications in urban and military-base locations was developed with 130-t weight and a maximum power of 1.5 MW from its PEMFC prime mover and auxiliary traction battery [92]. Carbon fibre composite tanks with a maximum pressure of $35 \mathrm{MPa}$ located at its roofline were used to store compressed hydrogen fuel. The mean thermodynamic efficiency of the power plant was observed to be $51 \%$. The locomotive completed a strict yard-switching (shunting) experiment during 2010, and on-board storage was enough for an 11-h operational shift. The experimental results indicate that it is technically feasible for hydrogen FC to be used in the rough and heavy rail environment. The locomotive performed perfectly in all respects and received good worker acceptance. It was pointed out [31] that many technical challenges which are not found in developing smaller prototype rail vehicles occur when full-scale locomotives are being designed and developed. For example, weight, centre of gravity, packaging, and safety are the important design factors considered. Harsh operational conditions, especially shock in-train loads, require component suspension and coupler systems capable of absorbing high energy. Therefore, hydrogen FC-powered hybrid rail vehicle scale-up by increasing mass, density, and power raises challenges mainly related to issues of power system layout, hydrogen storage, heat transfer, heating shielding, shock loads, and safety procedure.

\subsection{Control and strategies for energy management}

\subsubsection{Energy management and control systems}

The energy management and control systems (EMCSs) play a fundamental role in a hydrogen FC-powered hybrid rail vehicle system since they can take the advantage of energy source features and improve the efficient use of each energy source and consequently of the whole system and extend the lifetime of the components [84]. There are two control strategies-one is the optimisation-based control and the other is the rule-based control [43]. Rulebased strategies are appropriate for real-time control applications [23, 44]. Rules can be designed based on powertrain features or extracted from optimised algorithms, such as a global optimisation strategy based on dynamic programming (DP), and a fuzzy logic (FL) strategy. Optimisation-based strategies have been widely examined [23, 44], which can be classified into global optimisations (GO), instantaneous optimisations (IO), realtime optimisations (RO), etc.

An EMCS was presented in [45] for a dual-mode locomotive to minimise the consumption of hydrogen and to improve the lifetimes of the FC and ESS, based on rules that consider the energy and power densities because storage space is limited, and hydrogen is a bulky fuel. An EMCS based on an equivalent consumption minimisation strategy (ECMS) is presented in [23], which allows proper management of the tram energy during the overall drive cycle, saving $3.5 \%$ hydrogen consumption. A control strategy based on an ECMS was designed for a real tramway powered by a hybrid system [46, 47], and the results show the hybrid system's capability to meet necessary drive cycle outcomes, and the final battery $S_{\mathrm{c}}$ $(61.3 \%)$ is close to the initial one $(60 \%)$, which indicates that the selected battery capacity is correct, and there is no need for the battery to be charged at the end of the cycle. In [48, 84], an ECMS is adopted to control an FC to obtain the minimum hydrogen consumption based on the drive cycle parameters (including passenger numbers), while the FL control is used to manage the ESS. For a hydrogen FC 


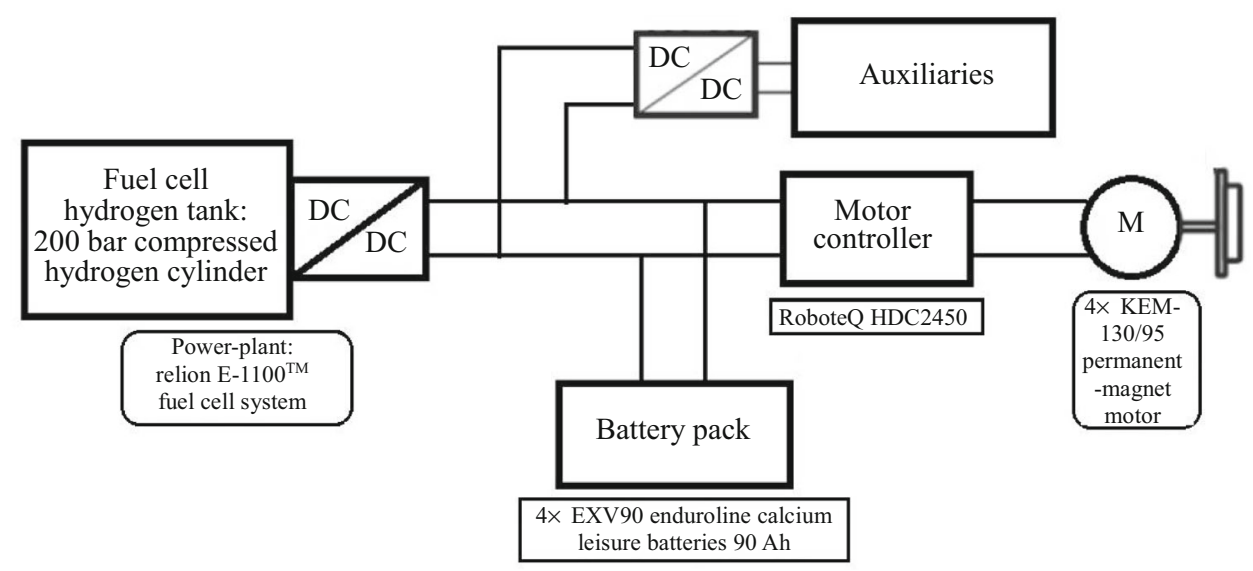

Fig. 4 Drive-train of the Hydrogen Pioneer [80]

hybrid locomotive [49], the simulations show that, based on the ECMS, when the load and speed change, the locomotive can response precisely and rapidly, meanwhile, the total equivalent hydrogen consumption is reduced, leading to the reduction in volume and weight of hydrogen storage system. An EMCS developed for an FC-SC hybrid locomotive is presented in [50] to meet the demand of dynamic performance, which is validated by reduced-scale testing. The results show that the proposed EMCS can improve the fuel utilisation rate, maintain the SC's $S_{\mathrm{c}}$ within a suitable range, and prolong the lifetime of the SC. A control system based on ECMS and FL control is designed in [82], and an ad hoc drive cycle is selected to test the system. The FC performs well in quasi-steady-state operations, and $50 \%$ efficiency is achieved. The ESS's $S_{\mathrm{c}}$ is maintained in preset intervals to avoid damage. The FL method is used to control the power flows of a hybrid locomotive [82], which can adapt the system behaviour to different conditions, presenting an optimum operation. Based on the comprehensive analysis of stochastic uncertainties in a tram operation, a suboptimal real-time power-sharing strategy taking into account operation uncertainties, fuel economy, and system durability is presented in [52], which comprises three modules, namely the fundamental real-time penalty power-sharing module, the FL-based differential power compensation module to achieve the performance degradation balancing between PEMFC and LIB, and the rain flow-based predictive $S_{\mathrm{c}}$ balancing module to realise adaptive updating relevant crucial variables of the above two modules. The proposed ECMS is confirmed to be more appropriate for PEMFC-based hybrid tram applications with minimum equivalent hydrogen consumption. Five control strategies are compared in [53], and the ECMS can be regarded as the most appropriate control strategy used in high-power hybrid rail vehicles.

\subsubsection{Methods of optimisation}

A methodology is presented in [54] for optimally sizing a hybrid energy system (HES) including LIB and PEMFC and minimising the total cost of HES with the constraints of the battery capacity and the FC limit, based on a modified model of the Krill Herd (KH) algorithm. An optimisation method for component sizing of a PEMFC-battery HES for passenger trains was presented in [83], in which the objective function is the minimisation of the cost of HES, subject to the constraints of the battery $S_{\mathrm{c}}$ limit, PEMFC capacity, and instantaneous power balance. The results indicate that the sizes of PEMFC and battery are dependent upon the specific EMCS setup, train average speed, track slope, fuel consumption, and dynamic behaviours. The particle swarm optimisation (PSO) and firefly algorithm (FA) are utilised to find the solution of an objective function in [55], which is created to decrease the cost of power sources, subject to the constraints of battery $S_{\mathrm{c}}$ limits, PEMFC rating, etc. The simulations validate that the heuristic FA studies provide a better component sizing with lower cost, small population size, and early convergence than PSO. A proposed strategy [56] uses the FA to optimise an ECMS to improve the drawback that the conventional ECMS takes insufficient consideration of the global performance for a hybrid rail vehicle. The results indicate cost reductions of up to $39.62 \%$ (operating mode control), $18.28 \%$ (FA-based operating mode control), and $13.81 \%$ (from ECMS). The model of a locomotive PEMFC system based on a support vector regression (SVR) is presented in [57] to examine the system dynamic behaviours under different operating conditions (PEMFC current, stack temperature, hydrogen pressure, and airflow); meanwhile, a modified PSO is used to regulate the hyperparameters of the SVR model for efficiently approximating 
the dynamic behaviours of the PEMFC and accurately predicting dynamic performance regarding the output voltage and power.

An optimal EMCS based on a sequential quadratic programming (SQP) algorithm was presented in [58], which ensures that the FC works in the high-efficiency range and the battery $S_{\mathrm{c}}$ is in the constrained range. An experiment has been done to validate the proposed EMCS, and the testing results indicate that the optimal EMCS performs better than an ECMS. An EMCS based on dynamic factor strategy is presented in [59] for a scaleddown hybrid locomotive system to restore more regenerative braking energy and ensure the safety of the hybrid system under the actual drive cycle. The proposed strategy, which is an instantaneous optimisation method and has a self-adaption function for various drive cycles, aims to obtain the least hydrogen consumption and higher system efficiency, and the testing results indicate that the proposed strategy can maintain the battery $S_{\mathrm{c}}$ better than an ECMS and can achieve a suitable performance of the $S_{\mathrm{c}}$, with the final $S_{\mathrm{c}}$ being close to the target value no matter the initial $S_{\mathrm{c}}$ of the battery. For a hybrid power system comprising hydrogen FC stacks and a set of flywheels, an innovative predictive logic is presented in [60] to manage power flows and minimise fuel consumption, and the results emphasise that considerable fuel savings can be accomplished. An EMCS based on dynamic following coefficient was proposed in [61], which can achieve an overall system efficiency above $44 \%$, and it has a powerful capacity to maintain the $S_{\mathrm{c}}$ of battery and extend the lifetime of battery.

FC-powered hybrid locomotive modelling and optimisation simulations are completed by the ADVISOR software in [83]. The power of the FC, battery, and motor are optimised by using a bisection algorithm under the necessary constraints, and the dynamic and economy performances are improved after optimisation. A global optimum operation and control approach for an FC-SC hybrid tram was proposed in [62], which comprises two parts, the first being the speed optimisation technique based on the minimal energy consumption to obtain the speed curve, and the other is the hybrid system control technique based on the minimum hydrogen consumption and on the Lagrangian algorithm to obtain the optimal output power curve. An optimisation approach for showing an efficient result of hydrogen consumption and speed trajectory was proposed in [63] in a PEMFC-based hybrid locomotive system. The efficiency of hydrogen consumption is maximised by using a new version of the Improved Pathfinder (IPF) algorithm. The IPF is used to solve the local optimum and fast convergence drawbacks during the maximisation process. The results demonstrate that the efficiency of the system and hydrogen saving are significantly improved. A state machine strategy based on droop control [64] is presented to correlate several power sources and to prevent the power demand from transient and rapid changes, and the average efficiency of $56.78 \%$ is achieved without lowering the performance for an EMCS of the hybrid tramway. An EMCS based on an adaptive droop control, which is combined with a multimode strategy and an ECMS, is proposed in [65] for a large-scale and high-power hybrid tramway. Besides, an adaptive control strategy $[66,67]$ is presented to deal with the power-sharing in a hybrid power system, considering system constraints, which contain the slow dynamics of FC and $S_{\mathrm{c}}$ of the battery. In [93], Pontryagin's minimum principle (PMP) is applied for a regenerative braking energy recovery strategy for a hydrogen FC-SC hybrid locomotive, which is intended to obtain an optimum braking speed curve that has the maximum braking recovery rate, and the results attest that the strategy can maximise SC absorption of braking energy and maintain SC's $S_{\mathrm{c}}$ in a reasonable range. It is indicated in [94] that, compared to a typical model predictive control strategy, the strategy based on PMP can result in up to $12.1 \%$ hydrogen savings.

Overall, a suitable and excellent EMCS can significantly improve the performance of an FC-powered hybrid locomotive, achieving less hydrogen consumption, higher overall system efficiency, longer lifetime of power sources, etc. Different energy management strategies can give significant differences in robustness and efficiency.

\subsection{Comparison with traditional rail vehicles}

Currently, a lot of research projects have been done to focus on the comparison of hydrogen FC hybrid rail vehicles with conventional diesel vehicles. The trip of a diesel-electric train is simulated and considered as a benchmark for the conceptual designs of a hydrogen FCpowered and a hydrogen FC hybrid vehicle in [20]. Powermodule drive system diagrams are shown in Fig. 5 for these three trains-a. diesel-electric; b. hydrogen FC; and c. hydrogen FC hybrid. For the same operational conditions, energy consumption reductions of $34 \%$ with the hydrogen FC power and 55\% with the hydrogen hybrid power are obtained compared to the original diesel-electric based on Table 1 which lists the primary energy consumed per journey $(1,548 \mathrm{kWh}$ for the original diesel-electric and $1,017 \mathrm{kWh}$ for the hydrogen FC power and $690 \mathrm{kWh}$ for hydrogen hybrid power). The WTW $\mathrm{CO}_{2}$ emissions are analysed, and they indicate a 55\% reduction for the hydrogen FC and $72 \%$ for the hydrogen FC hybrid with assumption that the hydrogen is generated from natural gas. These conclusions regarding energy savings do not agree with the published plots of power usage in literature [20]. The authors appear to have used installed power capability 

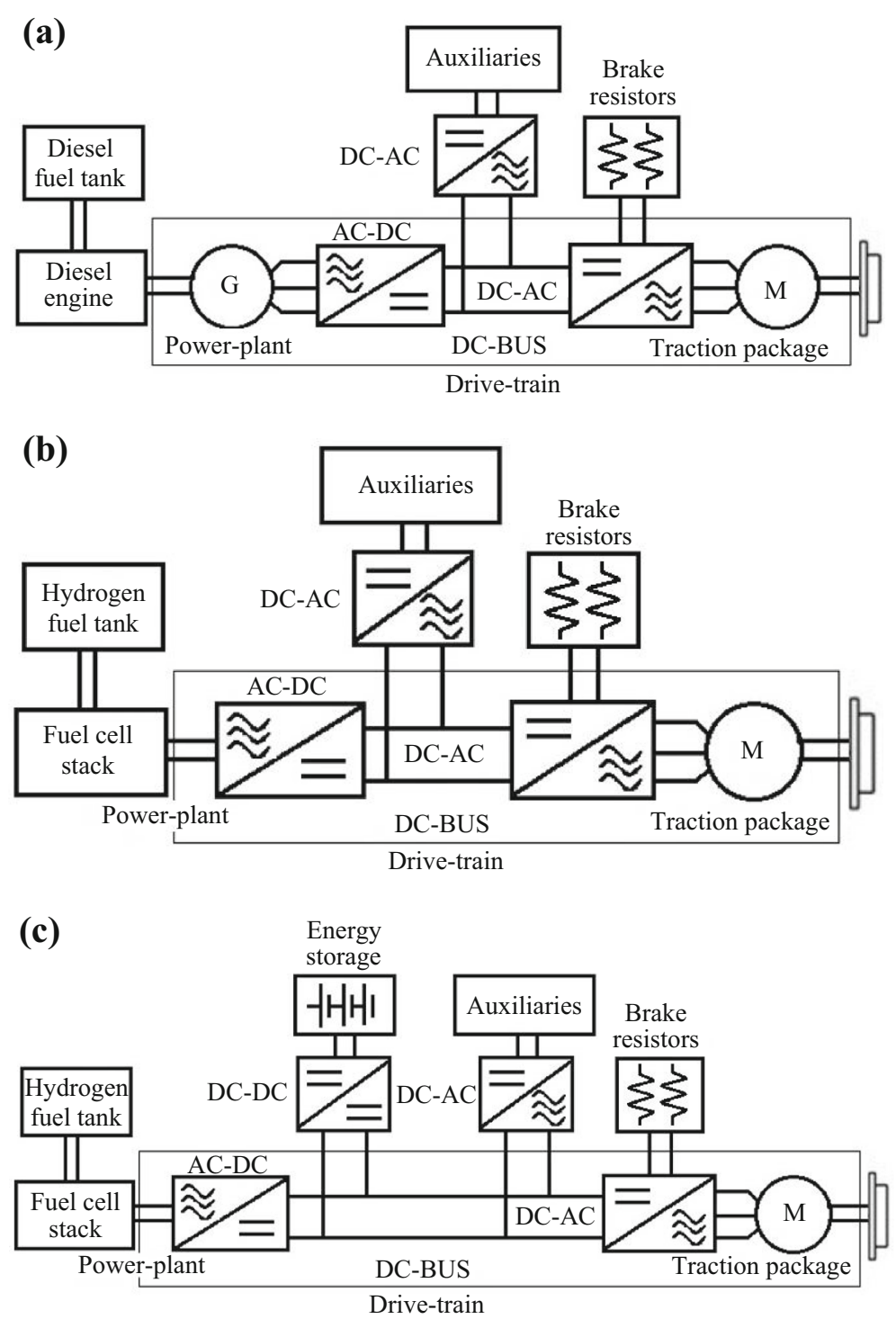

Fig. 5 Power-module drive systems for the three different trains: a diesel-electric; b hydrogen FC; c hydrogen FC hybrid [20]

rather that the traction comparison. The simulations are identical, with identical train loads and trip times, so the maximum traction power at the wheels is very similar, namely diesel $(470 \mathrm{~kW})$, hydrogen $(504 \mathrm{~kW})$ and hydrogen hybrid $(470 \mathrm{~kW})$. Examination of the plotted data reveals a duty cycle exactly the same for diesel and hydrogen with these maximum power levels being reached for $\sim 34 \%$ of the trip duration. The problem is illustrated by the incorrect calculation in Table 4 as follows. The correct calculation is shown in Table 5 .

Not surprisingly, the trip energies are very similar in Table 5 as the transport task was exactly the same. Neither diesel nor hydrogen power plants will be operating at full installed power, so it is quite incorrect to use this value in calculations as appears to be done in the paper and as confirmed in Table 4. The apparent incorrect energy reduction is in agreement with the authors of [20]. Using the power at the wheel, energy usage at the power plant can be estimated by examining the driveline differences. Normally, a diesel engine-to-wheel traction system has a loss of approximately $12 \%, 5 \%$ each for the electrical machines, and $2 \%$ for gearboxes. The hydrogen fuel cell does not need a generator, so a value of $7 \%$ might be appropriate. This means that energy usage at the source can be back calculated to be approximately, diesel 250/0.88 $=284 \mathrm{kWh}$ and hydrogen $268 / 0.93=288 \mathrm{kWh}$, so the hydrogen system is still $1 \%$ higher. To get a final figure, the authors of [20] need to further consider the thermal and cell efficiencies of the two systems so comparison of efficiency can be made based on fuel energy values. While emission savings are easily supported, energy consumption differences between diesel and hydrogen systems are expected to 
Table 4 Repeated calculation of diesel-hydrogen energy comparison in [20]

\begin{tabular}{llll}
\hline Parameters & \multicolumn{2}{l}{ Diesel-electric GTWHydrogen electric GTWSource of data } \\
\hline Installed power $(\mathrm{kW})$ & 2,100 & 1,400 & See Figs. 5 and 6 in [20] \\
Max power at the wheels $(\mathrm{kW})$ & 470 & 504 & See Table 13, Figs. 5 and 6 in [20] \\
Duty cycle (\%) & 34 & 34 & See Figs. 5 and 6 in [20] \\
Trip time (min) & 94 & 94 & See Table 13 in [20] \\
Trip energy (approx.) $(\mathrm{kWh})$ & 1,119 & 746 & Incorrect calculation: Installed power $\times$ duty cycle $\times$ hours \\
Apparent energy reduction & & $33 \%$ & Incorrect calculation \\
\hline
\end{tabular}

Table 5 Output energy calculation of diesel-hydrogen energy comparison using data from [20]

\begin{tabular}{llll}
\hline Parameters & \multicolumn{2}{l}{ Diesel-electric GTWHydrogen electric GTWSource of data } \\
\hline Installed power $(\mathrm{kW})$ & 2,100 & 1,400 & See Figs. 5 and 6 in [20] \\
Max power at the wheels $(\mathrm{kW})$ & 470 & 504 & See Table 13, Figs. 5 and 6 in [20] \\
Duty cycle (\%) & 34 & 34 & See Figs. 5 and 6 in [20] \\
Trip time (min) & 94 & 94 & See Table 13 in [20] \\
Trip energy (approx.) $(\mathrm{kWh})$ & 250 & 268 & Corrected recalculation: \\
& & $-7 \%$ & Power at the wheels $\times$ duty cycle $\times$ hours \\
Apparent energy reduction & & & Corrected recalculation
\end{tabular}

be small in terms of fuel value as the efficiencies of diesels and fuel cells are both nominally $40 \%$. For both diesel and hydrogen, the bigger fuel savings come from capturing energy from regenerative braking in storage.

A similar example is presented in [24]. A return trip was simulated to consider as a benchmark for the comparison among the diesel-electric, hydrogen FC, and hydrogen FC hybrid trains. These values are similarly questioned. In the case of both Refs. [20] and [24], the emission values are also questioned and should be reconfirmed before use.

The performance on energy and exergy efficiencies, fuel consumption, and environmental impact from a hybrid system is compared against a conventional diesel system to assess the viability of hydrogen FC-powered hybrid locomotive as a clean rail transportation alternative in [95]. A $53 \%$ reduction in GHG emissions is achieved, and the energy and exergy efficiencies improve slightly. The feasibility of SOFC-GT hybrid power systems is assessed as the prime mover in freight locomotives in [54], and it is found that the SOFC-GT required space is similar to existing diesel engines, and even in the diesel case, the SOFC-GT system gives remarkable savings in fuel and $\mathrm{CO}_{2}$ emissions, making it to be an attractive alternative for the rail industries. The WTW analyses have been performed for various transport modes to assess the impact of fuels and energy carriers on the whole supply chain. The WTW methodology to the rail sector appraises hydrogen as a potential energy carrier for rail vehicles [96].
Comparison of energy use and emissions of hydrogen FC-powered trains with a conventional light rail electric train is presented in [25]. The simulation results show that, although they have similar power-to-weight ratios, both conceptual trains finish a round trip quicker than the electric one. Because of the requirements to increase mass and volume, the hydrogen FC and hydrogen FC hybrid trains need additional energy of $10.1 \%$ and $10.7 \%$ more at the wheels for propulsion. The electric train, because of improved efficiencies all-round the energy route, consumes considerably less feedstock energy. Besides, the hydrogen FC and hydrogen FC hybrid trains generate $162 \%$ and $85 \%$ more $\mathrm{CO}_{2}$ emissions annually than the electric one. The technical feasibility of a hydrogen FC train and relevant disadvantages of implementation are demonstrated in [97], and the results show that PEMFC has a one-third life expectancy compared to a diesel engine. These factors illustrate the main challenges to hydrogen implementations that occurred in the rail sector. However, it is found that the amount of hydrogen required to operate the PEMFC trains is about half that needed by the ICE, indicating that PEMFC has the potential to lower operational costs. Hydrogen ICEs have not been developed in large sizes, and commercially available engines of the size needed by a locomotive demand further research and development. 


\section{Potential applications of hydrogen rail vehicles}

\subsection{Comparative assessment of available options}

Nowadays, the most common energy source used by various rail vehicles is still diesel. A comparative assessment based on $\mathrm{CO}_{2}$ emissions from four passenger train propulsion technologies was examined in [11], considering T1-conventional diesel (ICE), T2-electrified, T3-hydrogen ICE, and T4-hydrogen PEMFC trains. The T1 is a currently running train with locomotive model F59PH (weight of $118 \mathrm{t}$ and fuel capacity of $8410 \mathrm{~L}$ ) hauling 10 cars, and the T2, T3 and T4 technologies are supposed to replace $\mathrm{T} 1$ to travel a route length of $361 \mathrm{~km}$. For the T2, the GHG emissions from electricity production by natural gas and coal-burning power plants are accepted for consideration. Many hydrogen generation techniques are also considered, namely M1-steam methane reforming (SMR), M2-thermochemical copper-chlorine $(\mathrm{Cu}-\mathrm{Cl})$ cycle, M3-renewable energies (solar and wind power), and $\mathrm{M} 4-$ combined renewable energy and $\mathrm{Cu}-\mathrm{CI}$ cycle. The results demonstrate that a $\mathrm{T} 4$ fuelled by hydrogen generated from M4 is the most environmentally friendly power system, and its $\mathrm{CO}_{2}$ emissions are about $9 \%$ of a conventional diesel locomotive or electrified train that utilises the electricity from a coal-burning power plant. Hydrogen generated with $\mathrm{M} 2$ is a promising option to further decrease GHG emissions. By substituting a T1 train with $\mathrm{T} 3$ or $\mathrm{T} 4$ trains fuelled by $\mathrm{Cu}-\mathrm{Cl}$ based-hydrogen, the yearly $\mathrm{CO}_{2}$ emissions are decreased by 2260 and 3318 t per train. The results verify that moving from a conventional diesel train towards a zero-emissions hydrogen-powered train (i.e. hydrogen-fuelled ICE and PEMFC) provides significant environmental benefits.

The analysis on a life-cycle cost is performed in [98] for five light rail vehicles, namely a pantograph/catenary tram, a contact-rail tram, and three FC hybrid trams. For the study, a simplified life-cycle cost model is proposed in which the costs for initial tramway infrastructure and power supply, daily operation, and power plant replacement are considered. The lower initial costs of an FC hybrid tram occur compared to a pantograph/catenary tram or contact-rail tram, and the life-cycle costs of an FC hybrid tram highly depend on combined factors of hydrogen, FC, and battery prices. The GHG emissions of all the trams are almost equivalent. It is predicted that FC technology is developing, and as cost reduction of hydrogen and FC is foreseeable, FC hybrid trams will become progressively more competitive. Comparing the $\mathrm{CO}_{2}$ emissions of hydrogen vehicles against those from purely fossil fuel ones, Ref. [99] summarises the large benefits of utilising hydrogen in rail applications, where increasing trends of $\mathrm{CO}_{2}$ emissions from conventional trams are reversed as a result of the increasing use of hydrogen propulsions. Further reductions in $\mathrm{CO}_{2}$ emissions can be realised by lower-emitting hydrogen productions such as nuclear thermochemical production and electrolysis from wind, solar, and hydropower. The equivalent annual costs, benefit-cost ratio, payback period, and up-front investment are taken in [100] as the criteria to compare different power source technologies, based on the expected techno-economic data for years 2020, 2030, and 2050. The results suggest there is potential for FC and battery technologies to replace diesel on railways with low traffic volumes.

\subsection{Necessity of hydrogen rail vehicles in the light rail vehicle and suburban train operations}

As a result of their excellent passenger capacity, comfortable ride, low energy consumption, and long environmentally friendly service life, trams have become a popular light rail transportation option in large- and medium-sized cities. Light rail vehicles are one of the best candidates for FC technologies because of two reasons: firstly, the vehicle's large space allows generous powertrain component layouts, leading to the requirement for low numbers of hydrogen refuelling stations, and secondly, trams are the most appropriate choice due to the lowest energy consumption. PEMFC hybrid systems have been attempted and utilised in the propulsion systems for light rail vehicles and suburban cars [23] due to higher efficiency, regenerative braking energy capture, and practically zero emissions of air pollutants.

Electric trains (ET) and hydrogen FC trains (HT) generate zero emissions of pollutants at the point of use. For conventionally fuelled trains (CFT), ET, and HT, the outputs based on a $\mathrm{CO}_{2}$ emissions model in the period of 2017 to 2050 are presented under four National Grid electricity generation scenarios in the UK [101]. Four service categories (urban, regional, intercity, and high speed) are compared to private conventionally fuelled vehicles (CFV) and electric vehicles with the consideration of average distance travelled per trip under different passenger capacity levels $(125 \%, 100 \%, 75 \%, 50 \%$, and $25 \%)$. The output results show that, at $100 \%$ capacity, CFTs will generate one-fifth of the emissions of CFVs per kilometre per person by 2050 . Under the scenario of restricting global warming to less than a $2{ }^{\circ} \mathrm{C}$ temperature rise as set out in the Paris Agreement, by 2050, ETs and HTs will produce emissions of $7.14 \%$ and $20 \%$ of CFTs, respectively. 


\subsection{Necessity of hydrogen rail vehicles in heavy haul railway operations}

Possible $\mathrm{CO}_{2}$ emission mitigation options were studied for fuel alternatives for the Australian minerals industry and showed potential fuels being biodiesel, natural gas, or hydrogen in the medium to long term [102]. The huge bulk mineral transportation (coal, iron ore, and bauxite) in 2008 in Australia accounted for $99 \%$ of total GHG emissions associated with the core transport modes of rail and ship as the domestic transport mode is heavy haul rail operation mainly fuelled by diesel and the freight task is $\sim 1,000$ MGT per year. The large amount of GHG emissions therefore become the focus of mitigation proposals. It is suggested [102] that in the medium to longer term, hydrogen transport mode could be one of the possible strategies that can significantly alleviate GHG emissions.

It is assumed in [17] that diesel engines play a dominant role in rail transport at the global level currently at $70 \%$, followed by $30 \%$ being fully electric locomotives. The existing diesel engines, and so a large proportion of current fleets, do not depend on overhead catenary infrastructure. Due to the high infrastructure cost of corridor electrification, on-board hydrogen FC technologies for PMEFC and SOFC could become promising candidate to settle environmental issues, with zero local emissions (for PMEFC) and reduced emissions (for SOFC).

\section{Concluding remarks}

At present, theoretical and experimental studies have identified some potential solutions for clean rail transportation; among them, hydrogen power is one of the promising solutions. A lot of conceptual designs and simulations for the light rail hydrogen-powered vehicles have been completed, but no parallel developments of heavier freight and heavy haul hydrogen-powered locomotives were found.

It is evident that future hydrogen FC hybrid rail vehicles will probably be based on SOFC or PEMFC types. It seems that PEMFC is more suitable for light rail applications due to low working temperature, high efficiency, and quick start-up while the higher efficiency SOFC might find application for rail freight or heavy haul transportation.

The slow dynamic response of FCs has become a problem in some applications. In such cases, combining the hydrogen FC with an energy storage ESS to manage the power fluctuation can provide solutions. The analysis shows that the PEMFC or SOFC along with the ESS can perform better than PEMFC or SOFC systems alone.

The energy management and control systems play a vital role in hydrogen FC hybrid rail vehicle systems, and many such strategies have been designed. Implementing hybrid FC and ESS systems will not only improve the energy efficiency, but also will reduce the problem of exhaust emissions significantly.

Open Access This article is licensed under a Creative Commons Attribution 4.0 International License, which permits use, sharing, adaptation, distribution and reproduction in any medium or format, as long as you give appropriate credit to the original author(s) and the source, provide a link to the Creative Commons licence, and indicate if changes were made. The images or other third party material in this article are included in the article's Creative Commons licence, unless indicated otherwise in a credit line to the material. If material is not included in the article's Creative Commons licence and your intended use is not permitted by statutory regulation or exceeds the permitted use, you will need to obtain permission directly from the copyright holder. To view a copy of this licence, visit http://creativecommons. org/licenses/by/4.0/.

\section{References}

1. Koseki T (2010) Technologies for saving energy in railway operation: general discussion on energy issues concerning railway technology. IEEJ Trans Electr Electron Eng 5:285-290

2. Wikipedia (2021) Diesel locomotive. https://en.wikipedia.org/ wiki/Diesel_locomotive. Accessed 22 Jan 2021

3. Siddiqui O, Dincer I (2019) A review on fuel cell-based locomotive powering options for sustainable transportation. Arab J Sci Eng 44:677-693

4. Jones WD (2006) Hydrogen on track. IEEE Spectr 43(8):10-13

5. Hoffrichter A (2019) Hydrogen-rail (hydrail) development. Paper presented at H2@Rail Workshop, Lansing, MI. 27 Mar 2019.

6. Verdict Media Limited (2021) Railway technology: cordia iLint regional train. https://www.railway-technology.com/projects/ coradia-ilint-regional-train/. Accessed 20 April 2021

7. Gallucci M (2019) Hydrogen trains roll into service: A new hybrid locomotive signals a growing push for zero-emission rail technologies. IEEE Spectrum, 6 Aug 2019.

8. Miller AR, Peters J, Smith BE, Velev OA (2006) Analysis of fuel cell hybrid locomotives. J Power Sources 157:855-861

9. Hoffrichter A (2013) Hydrogen as an energy carrier for railway traction. Dissertation, The University of Birmingham.

10. Hoffrichter A, Hillmansen S, Roberts C (2010) Review and assessment of hydrogen propelled railway vehicles. In: IET conference on railway traction systems, Birmingham. 13-15 Apr 2010, pp 1-5

11. Haseli Y, Naterer GF, Dincer I (2008) Comparative assessment of greenhouse gas mitigation of hydrogen passenger trains. Int $\mathbf{J}$ Hydrogen Energy 33:1788-1796

12. Hollingsworth B, Cook A (1996) The great book of trains. Salamander Books Ltd

13. Spiryagin M, Cole C, Sun YQ, McClanachan M, Spiryagin V, McSweeney T (2014) Design and simulation of rail vehicles. CRC Press, Taylor \& Francis Group, Boca Rotan

14. Spiryagin M, Wolfs P, Cole C, Spiryagin V, Sun YQ, McSweeney T (2016) Design and Simulation of Heavy Haul Locomotives and Trains. CRC Press, Taylor \& Francis Group, Boca Rotan

15. Raj AK (2019) Futuristic and trendy eco-friendly emission-free hydrogen-oxygen fuel cell powered electric motor propelled automobiles and commuter locomotives. J Autom Auto Eng 4(3):22-26 
16. Furuta R, Kawasaki J, Kondo K (2010) Hybrid traction technologies with energy storage devices for nonelectrified railway lines. IEE J Trans Electr Electron Eng 5:291-297

17. Barbosa FC (2019) Fuel cell rail technology review: a tool for an autonomous rail electrifying strategy. In: Proceedings of the 2019 joint rail conference, Snowbird, UT, 9-12 Apr 2019

18. Din T, Hillmansen S, Ellis R (2018) Energy consumption and carbon dioxide emissions analysis for a concept design of a hydrogen hybrid railway vehicle. IET Electrical Syst Transp 8(2):112-121

19. Washing EM, Pulugurtha SS (2016) Energy demand and emission production comparison of electric, hydrogen and hydrogenhybrid light rail trains. Int J Rail Transp 4(1):55-70

20. Hoffrichter A, Hillmansen S, Roberts C (2016) Conceptual propulsion system design for a hydrogen-powered regional train. IET Electrical Syst Transp 6(2):55-66

21. Miller AR, Hess KS, Barnes DL, Erickson TL (2007) System design of a large fuel cell hybrid locomotive. J Power Sources 173:935-942

22. Peng F, Chen W, Liu Z, Li Q, Dai C (2014) System integration of China's first proton exchange membrane fuel cell locomotive. Int J Hydrogen Energy 39:13886-13893

23. Zhang W, Li J, Xu L, Ouyang M (2017) Optimization for a fuel cell/battery/capacity tram with equivalent consumption minimization strategy. Energy Convers Manage 134:59-69

24. Wikipedia (2021) Fuel cell. https://en.wikipedia.org/wiki/Fuel_ cell. Accessed 11 Jan 2021

25. Schroeder DJ, Majumdar P (2010) Feasibility analysis for solid oxide fuel cells as a power source for railroad road locomotives. Int J Hydrogen Energy 35:11308-11314

26. Carrette L, Friedrich KA, Stimming U (2001) Fuel cells-fundamentals and applications. Fuel Cells 1(1):5-39

27. Wang Y, Chen KS, Mishler J, Cho SC, Adroher XC (2011) A review of polymer electrolyte membrane fuel cells: technology, applications, and needs on fundamental research. Appl Energy 88(4):981-1007

28. Sopian K, Daud WW (2006) Challenges and future developments in proton exchange membrane fuel cells. Renew Energy 31:719-727

29. Kordesch K, Hacker V, Gsellmann J et al (2000) Alkaline fuel cells applications. J Power Sources 86(1):162-165

30. Bidault F, Brett DJL, Middleton PH, Brandon NP (2009) Review of gas diffusion cathodes for alkaline fuel cells. J Power Sources 187(1):39-48

31. US Department of Energy (2021) Comparison of fuel cell technologies. https://www.energy.gov/eere/fuelcells/comparisonfuel-celltechnologies. Accessed 28 Jan 2021

32. Yedavalli K, Guo L, Zinger DS (2011) Simple control system for a switcher locomotive hybrid fuel cell power system. IEEE Trans Ind Appl 47(6):2384-2390

33. Brenscheidt T, Janowitz K, Salge HJ, Wendt H, Brammer F (1998) Performance of ONSI PC25 PAFC cogeneration plant. Int J Hydrogen Energy 23(1):53-56

34. Chen X, Wang Y, Zhao Y, Zhou Y (2016) A study of double functions and load matching of a phosphoric acid fuel cell/heatdriven refrigerator hybrid system. Energy 101:359-365

35. Baron R, Wejrzanowski T, Szabłowski Ł et al (2018) Dual ionic conductive membrane for molten carbonate fuel cell. Int $\mathbf{J}$ Hydrogen Energy 43(16):8100-8104

36. Jienkulsawad P, Saebea D, Patcharavorachot Y, Kheawhom S (2018) Arpornwichanop A (2018) Analysis of a solid oxide fuel cell and a molten carbonate fuel cell integrated system with different configurations. Int J Hydrogen Energy 43(2):932-942

37. Guo L, Yedavalli K, Zinger D (2011) Design and modeling of power system for a fuel cell hybrid switcher locomotive. Energy Convers Manage 52:1406-1413
38. People's Daily (2010) China introduces first light-rail locomotive with new-energy fuel cells (29 Nov. 2010). http://en.people. cn/90001/90776/90882/7215009.html. Accessed 10 Jan 2021

39. Foster M (2017) Caltrain 2.0-Hydrogen Fuel Cell EMUs. https://www.mikeforster.net/wp-content/uploads/2017/07/ Caltrain-2.0-Hydrogen-Fuel-Cell-EMUs-Mike-Forster-v3.2.pdf. Accessed 20 Apr 2021

40. Sarma U, Ganguly S (2017) Determination of rating requirement for fuel-cell-battery hybrid energy system to substitute the diesel locomotives of Indian railway. In: 14th IEEE India Council International Conference (INDICON), Roorkee, India, pp 1-6

41. Sarma U, Ganguly S (2018) Modelling and cost-benefit analysis of PEM fuel-cell-battery hybrid energy system for locomotive application. In: 2018 Technologies for smart-city energy security and power (ICSESP), Bhubaneswar, India, pp 1-5

42. Zhang G, Chen W, Li Q (2017) Modeling, optimization and control of a FC/battery hybrid locomotive based on ADVISOR. Int J Hydrogen Energy 42:18568-18583

43. Zheng CH, Oh CE, Park YI, Cha SW (2012) Fuel economy evaluation of fuel cell hybrid vehicles based on equivalent fuel consumption. Int J Hydrogen Energy 37:1790-1796

44. Unlubayir C, Nemeth T, Meishner F, Peng H, Deng K, Sauer DU (2019). Simulation model with an optimal operation strategy for a hybrid train powered by a battery and a fuel cell. In: 2019 IEEE vehicle power and propulsion conference (VPPC), Hanoi, Vietnam, pp 1-5

45. Mendoza DS, Acevedo P, Jaimes JS, Solano J (2019) Energy management of a dual-mode locomotive based on the energy sources characteristics. In: 2019 IEEE vehicle power and propulsion conference (VPPC), Hanoi, Vietnam, pp 1-4

46. Torreglosa JP, Jurado F, Garcia P, Fernández LM (2011) Hybrid fuel cell and battery tramway control based on an equivalent consumption minimization strategy. Control Eng Pract 19:1182-1194

47. Garcia P, Torreglosa JP, Fernández LM, Jurado F (2012) Viability study of a FC-battery-SC tramway controlled by equivalent consumption minimization strategy. Int J Hydrogen Energy 37:9368-9382

48. Piraino F, Fragiacomo P (2020) Design of an equivalent consumption minimization strategy-based control in relation to the passenger number for a fuel cell tram propulsion. Energies 13:4010

49. Shang W, Yu S, Zhang G, Li Q, Chen W (2017) Fuel cell hybrid locomotive system based on equivalent consumption minimization strategy. In: 2017 Chinese automation congress (CAC), Jinan, 20-22 Oct 2017, pp 2457-2461

50. Hong Z, Han Y, Li Q, Chen W, (2016) Design of energy management system for fuel cell/supercapacitor hybrid locomotive. In: 2016 IEEE vehicle power and propulsion conference (VPPC), Hangzhou, 17-20 Oct 2016, pp 1-5

51. Jiang Z, Chen W, Dai C, Cheng Z (2010) Optimal Energy Management for a Fuel Cell Hybrid Locomotive. In: 2010 Seventh international conference on fuzzy systems and knowledge discovery (FSKD 2010), Yantai, China, pp 1320-1323.

52. Peng F, Zhao Y, Chen T, Zhang X, Chen W, Zhou D, Li Q (2018) Development of robust suboptimal real-time power sharing strategy for modern fuel cell based hybrid tramways considering operational uncertainties and performance degradation. Appl Energy 226:503-521

53. García P, Torreglosa JP, Fernández LM, Jurado F (2013) Control strategies for high-power electric vehicles powered by hydrogen fuel cell, battery and supercapacitor. Expert Syst Appl 40:4791-4804

54. Guo Y, Dai X, Jermsittiparsert K, Razmjooy N (2020) An optimal configuration for a battery and PEM fuel cell-based 
hybrid energy system using developed Krill herd optimization algorithm for locomotive application. Energy Rep 6:885-894

55. Ajayan S, Selvakumar AI (2020) Implementation of firefly algorithm in optimal sizing of proton exchange membrane fuel cell -battery hybrid locomotive. Int J Renew Energy Res, 10(2)

56. Zhang H, Yang J, Zhang J, Song P, Xu X (2019) A firefly algorithm optimization-based equivalent consumption minimization strategy for fuel cell hybrid light rail vehicle. Energies 12:2665

57. Li Q, Chen W, Liu Z, Guo A, Huang J (2014) Nonlinear multivariable modeling of locomotive proton exchange membrane fuel cell system. Int J Hydrogen Energy 39:13777-13786

58. Wang X, Li Q, Wang T, Han Y, Chen W (2019). Optimized energy management strategy based on sqp algorithm for pemfc hybrid locomotive. In: 2019 IEEE transportation electrification conference and expo, Asia-Pacific (ITEC Asia-Pacific), Seogwipo-si, Korea (South), pp 1-5

59. Hong Z, Li Q, Han Y, Shang W, Zhu Y, Chen W (2018) An energy management strategy based on dynamic power factor for fuel cell/battery hybrid locomotive. Int $\mathrm{J}$ Hydrogen Energy 43:3261-3272

60. D'Ovidio G, Ometto A, Valentini O (2020) A novel predictive power flow control strategy for hydrogen city rail train. Int $\mathbf{J}$ Hydrogen Energy 45:4922-4931

61. Hong Z, Zhu Y, Shang W, Li Q, Chen W (2017) Research of energy management strategy for fuel cell/battery hybrid locomotive. In: 2017 IEEE transportation electrification conference and expo, Asia-Pacific (ITEC Asia-Pacific), Harbin, pp 1-5

62. Yan Y, Li Q, Huang W, Chen W (2021) Operation optimization and control method based on optimal energy and hydrogen consumption for the fuel cell/supercapacitor hybrid tram. IEEE Trans Ind Electron 68(2):1342-1352

63. Yuan Z, Li H, Yousefi H (2021) Optimal hydrogen consumption of fuel cell-based locomotive using speed trajectory optimization by Improved Pathfinder algorithm. J Clean Prod 278:123430

64. Li Q, Yang H, Han Y, Li M, Chen W (2016) A state machine strategy based on droop control for an energy management system of PEMFC-battery supercapacitor hybrid tramway. Int J Hydrogen Energy 41:16148-16159

65. Li Q, Wang T, Dai C, Chen W, Ma L (2018) Power management strategy based on adaptive droop control for a fuel cell-batterysupercapacitor hybrid tramway. IEEE Trans Veh Technol 67(7):5658-5670

66. Wu C, Chen J, Xu C, Liu Z (2017) Real-time adaptive control of a fuel cell/battery hybrid power system with guaranteed stability. IEEE Trans Control Syst Technol 25(4):1394-1405

67. Peng H, Li J, Löwenstein L, Hameyer K (2020) A scalable, causal, adaptive energy management strategy based on optimal control theory for a fuel cell hybrid railway vehicle. Appl Energy 267:114987

68. Dincer I, Zamfirescu C (2016) A review of novel energy options for clean rail applications. J Nat Gas Sci Eng 28:461-478

69. Miller A, Berg GVD, Barnes DL, Eisele RI, Tanner DM, Vallely JM, Lassiter DA, (2012). Fuel cell technology in underground mining. The Southern African Institute of Mining and Metallurgy Platinum 2012. https://www.911metallurgist.com/blog/ wp-content/uploads/2016/02/Fuel-cell-technology-inunderground-mining.pdf. Accessed 15 Apr 2021

70. Martinez AS, Brouwer J, Samuelsen GS (2012) Feasibility study for SOFC-GT hybrid locomotive power: part I. Development of a dynamic 3.5MW SOFC-GT FORTRAN model. J Power Sources 213:203-217

71. Martinez AS, Brouwer J, Samuelsen GS (2012)Feasibility study for SOFC-GT hybrid locomotive power: part II. System packaging and operating route simulation. J Power Sources 213:358-374

72. Ahrend P, Azizi A, Brouwer J, Samuelsen GS (2019) A solid oxide fuel cell-gas turbine hybrid system for a freight rail application. In: Proceedings of the ASME 2019, 13th international conference on energy sustainability, Bellevue, WA, USA, 14-17 July 2019

73. Murray-Smith D (2020) Modelling and simulation of hybrid electric trains powered by hydrogen fuel cells and batteries for routes in the highlands of Scotland: preliminary results. In: Technical Report for the Scottish Association of Public Transport.

74. Murray-Smith D (2020) Design options for hybrid trains powered by hydrogen fuel cells and batteries for routes in the highlands of Scotland: results for the case of a three-coach multiple-unit train. In: Technical Report for the Scottish Association of Public Transport.

75. Piraino F, Fragiacomo P (2020) A multi-method control strategy for numerically testing a fuel cell-battery-supercapacitor tramway. Energy Conver Manag, 225:113481

76. Abdelrahman AS, Attia Y, Woronowicz K, Youssef MZ (2016) Hybrid fuel cell/battery rail car: a feasibility study. IEEE Trans Transp Electrific 2(4):493

77. Longo M, Brenna M, Zaninelli D, Ceraolo M, Lutzemberger G and Poli D (2019) Fuel-cell based propulsion systems for hybrid railcars. In: IEEE Milan Power Tech, Milan, Italy, pp 1-6

78. Li Q, Huang W, Chen W, Yan Y, Shang W, Li M (2019) Regenerative braking energy recovery strategy based on Pontryagin's minimum principle for fell cell/supercapacitor hybrid locomotive. Int J Hydrogen Energy 44:5454-5461

79. Emadi A, Williamson SS, Khaligh A (2006) Power electronics intensive solutions for advanced electric, hybrid electric, and fuel cell vehicular power systems. IEEE Trans Power Electron 21(3):567-577

80. Coombe D, Fisher D, Hoffrichter A, Kent S et al (2016) Development and design of a narrow-gauge hydrogen-hybrid locomotive. Proc IMechE Part F J Rail Rapid Transit 230(1):181-192

81. Tsukahara K, Kondo K (2013) A study on methods to design and select energy storage devices for fuel cell hybrid powered railway vehicles, In: IECON 2013-39th annual conference of the IEEE Industrial Electronics Society, Vienna, pp 4534-4539

82. Fragiacomo P, Piraino F (2018) Numerical modelling of a PEFC powertrain system controlled by a hybrid strategy for rail urban transport. J Energy Storage 17:474-484

83. Sarma U, Ganguly S (2018) Determination of the component sizing for the PEM fuel cell-battery hybrid energy system for locomotive application using particle swarm optimization. J Energy Storage 19:247-259

84. Fragiacomo P, Piraino F (2019) Fuel cell hybrid powertrains for use in Southern Italian railways. Int $\mathrm{J}$ Hydrogen Energy 44:27930-27946

85. Cho I, Lee B, Park S, Ryu J, Kim J (2020) Designing highvoltage and large-capacity battery packs for fuel-cell hybrid railroad propulsion system. Electronics 9(8):1259

86. Fragiacomo P, Piraino F (2017) Energy performance of a FC hybrid system for rail vehicle propulsion. Energy Procedia 126:1051-1058

87. Abbas M, Cho I, Kim J (2019) Reliability-constrained optimal sizing and rechargeable battery selection for improved load distribution in a fuel-cell hybrid railway propulsion system. Energy Convers Manag 196(15):1167-1179

88. Hoffrichter A, Fisher P, Tutcher J, Hillmansen S, Roberts C (2014) Performance evaluation of the hydrogen-powered prototype locomotive 'Hydrogen Pioneer'. J Power Sources 250:120-127 
89. Chen W, Peng F, Liu Z, Li Q, Dai C (2013) System integration of China's first PEMFC locomotive. J Mod Transp 21(3):163-168

90. Yan Y, Li Q, Chen W, Su B, Liu J, Ma L (2019) Optimal energy management and control in multimode equivalent energy consumption of FC/supercapacitor of hybrid electric tram. IEEE Trans Ind Electron 66(8):6065-6076

91. Akhoundzadeh MH, Raahemifar K, Panchal S, Samadani E, Haghi E, Fraser R, Fowler M (2019) A conceptualized hydrail powertrain: a case study of the union pearson express route. World Electric Veh J 10:32

92. Miller AR, Erickson TL, James Dippo L, Eisele RI, Johnson MD, Lambrecht $T$ (2011) Hydrogen fuel-cell locomotive: switching and power-to-grid demonstrations. In: 9th World congress on railway research, Lille, France, 22-26 May 2011

93. Li Q, Chen Z, Liu W, Li M, Ma L (2015) Development of energy management system based on a power sharing strategy for a fuel cell-battery-supercapacitor hybrid tramway. J Power Sources 279:267-280

94. Deng K, Peng H, Dirkes S, Gottschalk J, Ünlübayir C, Thul A, Lowenstein L, Pischinger S, Hameyer K (2021) An adaptive PMP-based model predictive energy management strategy for fuel cell hybrid railway vehicles. eTransportation 7:100094.

95. Hogerwaard J, Dincer I (2016) Comparative efficiency and environmental impact assessments of a hydrogen assisted hybrid locomotive. Int J Hydrogen Energy 41:6894-6904
96. Hoffrichter A, Miller AR, Hillmansen S, Roberts C (2012) Wellto-wheel analysis for electric, diesel and hydrogen traction for railways. Transp Res Part D 17:28-34

97. Marin GD, Naterer GF, Gabriel K (2010) Rail transportation by hydrogen vs. electrification e case study for Ontario, Canada, II: energy supply and distribution. Int $\mathbf{J}$ Hydrogen Energy 35:6097-6107

98. Zhang W, Li J, Xu L, Ouyang M, Liu Y, Han Q, Li K (2016) Comparison study on life-cycle costs of different trams powered by fuel cell systems and others. Int $\mathrm{J}$ Hydrogen Energy 41:16577-16591

99. Cuda P, Dincer I, Naterer CF (2012) Hydrogen utilization in various transportation modes with emissions comparisons for Ontario, Canada. Int J Hydrogen Energy 37:634-643

100. Zenith F, Isaac R, Hoffrichter A, Thomassen MS, Møller-Holst S (2020) Techno-economic analysis of freight railway electrification by overhead line, hydrogen and batteries: case studies in Norway and USA. Proc IMechE Part F J Rail Rapid Transit 234(7):791-802

101. Logana KG, Nelsonb JD, McLellanc BC, Hastingsa A (2020) Electric and hydrogen rail: potential contribution to net zero in the UK, Transp Res Part D, 87:102523

102. Li Y, Corder GD, McLellan BC (2011) Transport in the minerals industry-contributions to greenhouse gas emissions and potential for mitigation. Miner Eng 24:1430-1439 